\title{
Cicer turcicum: A New Cicer Species and Its Potential to Improve Chickpea
}

OPEN ACCESS

Edited by:

Aditya Pratap,

Indian Institute of Pulses Research

(ICAR), India

Reviewed by:

Sarvjeet Singh,

Punjab Agricultural University, India

Mahendar Thudi,

International Crops Research Institute

for the Semi-Arid Tropics (ICRISAT),

India

Sushil Kumar Chaturvedi,

Rani Lakshmi Bai Central Agricultural

University, India

*Correspondence:

Cengiz Toker

toker@akdeniz.edu.tr

Specialty section:

This article was submitted to

Plant Breeding,

a section of the journal

Frontiers in Plant Science

Received: 01 February 2021

Accepted: 17 March 2021

Published: 15 April 2021

Citation:

Toker C, Berger J, Eker T, Sari D,

Sari H, Gokturk RS, Kahraman A, Aydin B and von Wettberg EJ (2021) Cicer turcicum: A New Cicer Species and Its Potential to Improve Chickpea.

Front. Plant Sci. 12:662891.

doi: 10.3389/fpls.2021.662891
Cengiz Toker ${ }^{1 *}$, Jens Berger ${ }^{2}$, Tuba Eker ${ }^{1}$, Duygu Sari ${ }^{1}$, Hatice Sari', Ramazan Suleyman Gokturk ${ }^{3}$, Abdullah Kahraman ${ }^{4}$, Bilal Aydin ${ }^{4}$ and Eric J. von Wettberg 5

1 Department of Field Crops, Akdeniz University, Antalya, Turkey, ${ }^{2}$ CSIRO Agriculture and Food, Wembley, WA, Australia, ${ }^{3}$ Department of Biology, Akdeniz University, Antalya, Turkey, ${ }^{4}$ Department of Field Crops, Harran University, Şanliurfa, Turkey, ${ }^{5}$ Department of Plant and Soil Science and Gund Institute for Environment, University of Vermont, Burlington, VT, United States

Genetic resources of the genus Cicer L. are not only limited when compared to other important food legumes and major cereal crops but also, they include several endemic species with endangered status based on the criteria of the International Union for Conservation of Nature. The chief threats to endemic and endangered Cicer species are over-grazing and habitat change in their natural environments driven by climate changes. During a collection mission in east and south-east Anatolia (Turkey), a new Cicer species was discovered, proposed here as C. turcicum Toker, Berger \& Gokturk. Here, we describe the morphological characteristics, images, and ecology of the species, and present preliminary evidence of its potential utility for chickpea improvement. C. turcicum is an annual species, endemic to southeast Anatolia and to date has only been located in a single population distant from any other known annual Cicer species. It belongs to section Cicer M. Pop. of the subgenus Pseudononis M. Pop. of the genus Cicer L. (Fabaceae) and on the basis of internal transcribed spacer (ITS) sequence similarity appears to be a sister species of $C$. reticulatum Ladiz. and C. echinospermum P.H. Davis, both of which are inter-fertile with domestic chickpea (C. arietinum L.). With the addition of $C$. turcicum, the genus Cicer now comprises 10 annual and 36 perennial species. As a preliminary evaluation of its potential for chickpea improvement two accessions of $C$. turcicum were field screened for reproductive heat tolerance and seeds were tested for bruchid resistance alongside a representative group of wild and domestic annual Cicer species. C. turcicum expressed the highest heat tolerance and similar bruchid resistance as C. judaicum Boiss. and C. pinnatifidum Juab. \& Spach, neither of which are in the primary genepool of domestic chickpea. Given that $C$. arietinum and $C$. reticulatum returned the lowest and the second lowest tolerance and resistance scores, C. turcicum may hold much potential for chickpea improvement if its close relatedness supports interspecific hybridization with the cultigen. Crossing experiments are currently underway to explore this question.

Keywords: Cicer, new species, genetic resources, heat tolerance, bruchid resistance 


\section{HIGHLIGHTS}

- We found that a new species endemic to East Anatolia, Turkey, which we have described and illustrated.

- The new species belongs to the same group with C. arietinum L., C. reticulatum Ladiz., and C. echinospermum P.H. Davis in the genus Cicer L. (Fabaceae) according to ITS sequencing.

- Based on preliminary studies, C. turcicum is tolerant to some abiotic and biotic stresses including heat, and bruchid that could be used in interspecific crosses to improve domesticated chickpea.

\section{INTRODUCTION}

The genus Cicer L. has a Rand Distribution, with a center of diversity scattered around the fringes of Africa as the continent has dried over the past few million years (Pokorny et al., 2015). Cicer species are from the Atlas Mountains and Canary Islands, in the Ethiopian highlands, to the Balkans and Caucasia, and into South and Central Asia. The richest density of Cicer species occur in the Anatolia-Turanian phytogeographic region (van der Maesen, 1972). The genus, despite earlier classifying in the tribe Vicieae Alefeld (1859), has been classified in its own tribe, Cicereae Alef. (Kupicha, 1977; Nozzolillo, 1985; van der Maesen, 1987). In a Cicer monograph, van der Maesen (1972) recognized 39 Cicer species including 31 perennials and eight annuals, including domesticated chickpea (Cicer arietinum L.). Since 1972 to 2007, the following Cicer species including C. heterophyllum Contandr., Pamukc. \& Quezel (Contandriopoulos et al., 1972) from Mediterranean region of Turkey, C. reticulatum Ladiz. (Ladizinsky, 1975) from south eastern Turkey, C. canariense A. Santos \& G.P. Lewis from the Canary Islands (Santos-Guerra and Lewis, 1986), C. rassuloviae Linczevski (Czrepanov, 1981), C. laetum Rassulova \& Sharipova (Rassulova and Sharipova, 1992), and C. tragacanthoides Jaubert \& Spach var. turcomanicum Popov from Turanian region were added to the genus (van der Maesen, 1984; van der Maesen et al., 2007). C. uludereensis Donmez (2011), C. floribundum Fenzl. var. amanicola M. Ozturk \& A. Duran, C. heterophyllum Contandr., Pamukc. \& Quezel var. kassianum M. Ozturk \& A. Duran and C. incisum (Willd.) K. Maly subsp. serpentinica M. Ozturk \& A. Duran were more recently added as new perennial Cicer taxa (Ozturk et al., 2011, 2013). Throughout that period only a single new annual wild Cicer species was added. C. reticulatum, now considered the wild progenitor of domesticated chickpea, was discovered in Dereici, Savur district, Mardin province, Turkey by Ladizinsky (1975). As a result of these discoveries, by 2020 the number of species in the genus Cicer was recognized as 45 species with nine annuals and 36 perennials. Importantly, as outlined below, only two of previously known eight annual wild Cicer species (C. reticulatum and C. echinospermum P.H. Davis) are in the primary and secondary gene pools of cultivated chickpea and are readily inter-fertile with chickpea (Ladizinsky and Adler, 1976a; van der Maesen et al., 2007; Smykal et al., 2015).
Among the annual Cicer species, $C$. arietinum is the sole species under domestication and worldwide grown in 60 countries with production quantity of 17.2 million tons from an area of 17.8 million ha in 2018 (FAOSTAT, 2020). Domesticated chickpeas with two varietal groups such as desi having pigmented plants, flowers and seeds and kabuli having non-pigmented plants, flowers and seeds were mainly grown in Indian sub-continued and Mediterranean region, respectively (Penmetsa et al., 2016). They are a significant source of protein, carbohydrates, vitamins, minerals and unsaturated fatty acids. Chickpeas not only possess characteristics for a balanced diet, especially for poor populations throughout the world (Jukanti et al., 2012; Pradhan et al., 2014; Upadhyaya et al., 2016; JimenezLopez et al., 2020; Sab et al., 2020), but are also important for sustainable agriculture since fixing atmospheric nitrogen to soil via special bacteria provides rotational value to subsequent crops (Afonso-Grunz et al., 2014; Marques et al., 2020b). With climate change, the continued importance of chickpeas depends on their capacity to adapt to adverse environments (Roorkiwal et al., 2014; Ahmad et al., 2016; Deokar and Tar'an, 2016; Pang et al., 2017; Marques et al., 2020a). Gross production value of domesticated chickpea in 2016 has been estimated to be about 5.9 billion $\$$ in the world (FAOSTAT, 2020).

Germplasm resources of annual Cicer are not only very limited when compared to cereals and other important food legumes (Berger et al., 2003; Smykal et al., 2015; Foyer et al., 2016; Dwivedi et al., 2019) but also some include several endemic species with endangered status based on the criteria of the International Union for Conservation of Nature (Ozturk, 2011; Talip et al., 2018; Tekin et al., 2018). This is very relevant for chickpea, given the limited diversity of the cultigen, and the ongoing need for new sources of diversity to exploit in crop improvement (Abbo et al., 2003). Currently only two annual Cicer species (C. reticulatum and C. echinospermum) are crossable to cultivated chickpea, but domesticated chickpea is not crossable with other species in the tertiary genepool including C. bijugum K.H. Rech., C. chorassanicum (Bge) Popov, C. cuneatum Hochst. ex Rich, C. echinospermum, C. judaicum Boiss., C. pinnatifidum Jaub. \& Spach, $C$. reticulatum, and C. yamashitae Kitamura (van der Maesen et al., 2007). C. bijugum, C. echinospermum, C. pinnatifidum, and C. reticulatum are native species of Anatolia and Middle-Eastern regions, while C. cuneatum occurs in Ethiopia, south-east of Egypt, north of Sudan and Saudi Arabia, C. chorassanicum and C. yamashitae are distributed to north and north-east of Iran and Afghanistan, and C. judaicum is grown in MiddleEastern region (Robertson et al., 1995; Berger et al., 2003). While C. judaicum was incorrectly listed in Turkey (Robertson et al., 1995), only C. bijugum, C. echinospermum, C. pinnatifidum, and C. reticulatum have been found in Anatolia, Turkey (Davis, 1970; van der Maesen, 1972; Berger et al., 2003; Ozturk, 2011; Ozturk et al., 2011).

In an effort to expand on these limited crop wild relative resources for chickpea, a Cicer collection mission focusing particularly on C. echinospermum and C. reticulatum was undertaken largely in south-eastern and eastern Turkey from 2013 to 2015 (Toker et al., 2014; Berger et al., 2017, 2018; von Wettberg et al., 2018), with opportunistic side trips from 


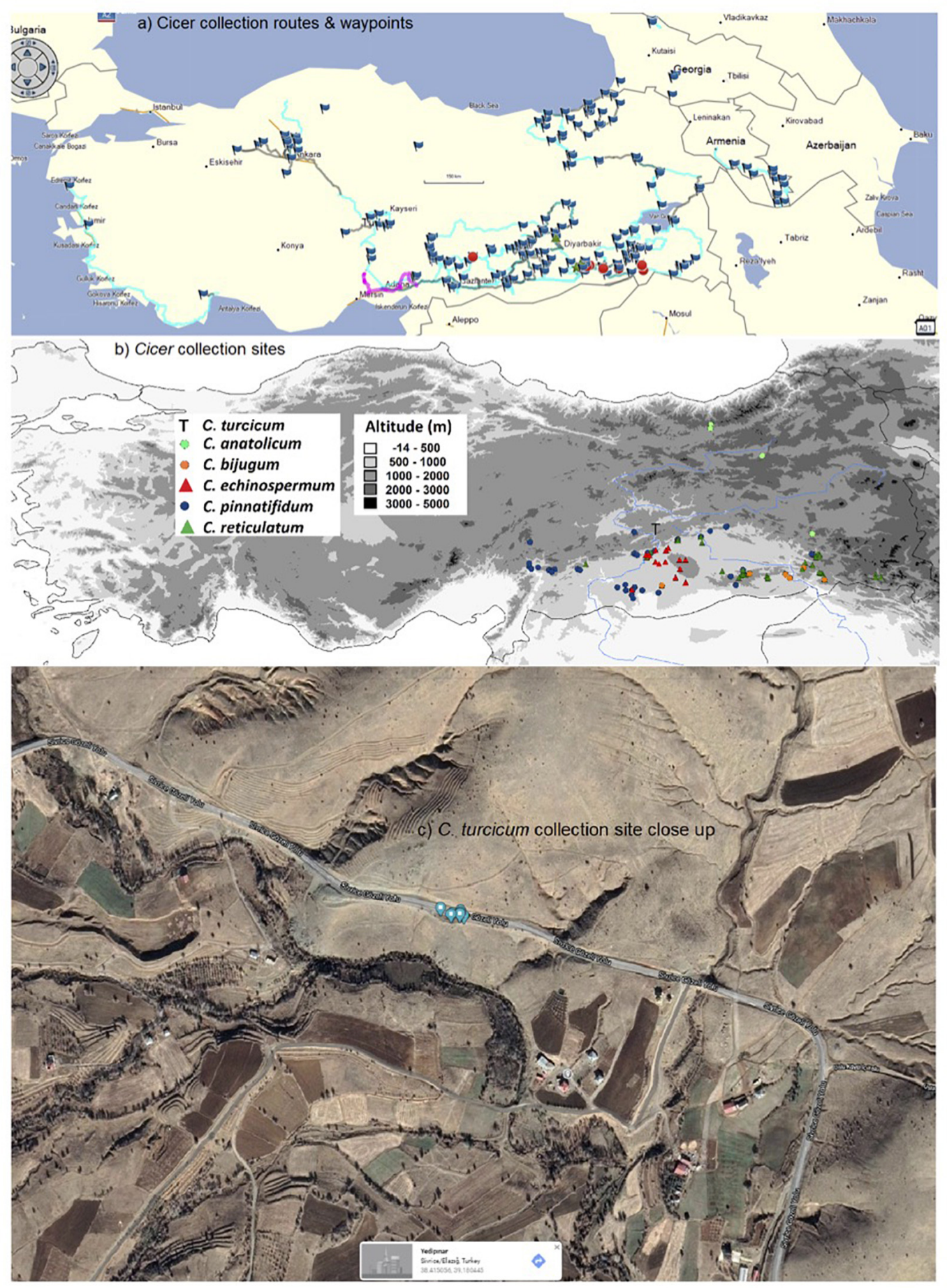

FIGURE 1 | West Asian Cicer survey (2013-18) routes and waypoints (a), collection sites classified by species (b), and close-up of the sole C. turcicum collection site at Yedipinar collection site, Sivrice district, Elazig province, Turkey. (Image from Google maps, Map data @2021, Australia) (c).

2016 to 2018 (Figure 1). During the collection mission, ca 590 accessions of C. bijugum, C. echinospermum, C. pinnatifidum, and $C$. reticulatum were collected from 91 sites and partially evaluated for their adaptive traits (Kahraman et al., 2017; Talip et al., 2018; von Wettberg et al., 2018; Reen et al., 2019;
Berger et al., 2020; Newman et al., 2020). This mission covered a huge range of locations throughout Turkey and beyond and collected a new species thus far unknown to the scientific world at only a single site (Figure 1). In the present study we propose this new species as $C$. turcicum, describe its known distribution and 
ecology, its morphological characteristics and relatedness to other Cicer species using internal transcribed spacer (ITS) sequencing. Finally, we undertake a preliminary evaluation for its utility for chickpea improvement by studying the species tolerance to heat in the reproductive stage and seed resistance to the bruchid, Callosobruchus chinensis L.

\section{MATERIALS AND METHODS}

\section{Cicer Survey and Collection Missions}

Cicer survey and collection missions were conducted from 2013 to 2018 focusing largely on eastern and south-eastern Anatolia with opportunistic side trips through central and western Turkey, southern Armenia, central and western Georgia (Figure 1a). Populations were surveyed in early spring so that plants could be identified using floral characteristics. This entailed random survey of potential collection sites (see waypoints in Figure 1a) by $1-5$ scientists searching for any wild Cicer species, with a focus on C. echinospermum and C. reticulatum, and opportunistically recording the presence of any wild Lens and Pisum relatives (Smýkal et al., 2018). Cicer leaf material was collected on a single plant basis to facilitate genetic studies, all samples being individually geo-referenced using a Garmin Montana 650 (von Wettberg et al., 2018). Geo-referenced soil samples were also taken at this time. Mature seeds were collected on an individual plant basis in late spring/early summer and georeferenced as before.

\section{Collection Site Climatic Data}

Collection site climate data (altitude, monthly mean, minimum and maximum temperature, and precipitation) was extracted at $30 \mathrm{~s}$ resolution (ca. $1 \mathrm{~km}$ grid) from WorldClim ( ${ }^{1} \mathrm{Hijmans}$ et al., 2005). Additional climate descriptors (monthly mean frost days, rain days, precipitation coefficients of variance, relative humidity, sun hours, wind speed) were extracted at $10 \mathrm{~min}$ resolution (ca. $12 \mathrm{~km}$ grid) ( ${ }^{2} \mathrm{New}$ et al., 2002). Similar climate data were also extracted directly from the weather station at the Elazig airport (892 $\mathrm{m}$ asl), $24.1 \mathrm{~km}$ distant from the Yedipinar collection site (1,548 $\mathrm{m}$ asl) and at lower elevation (892 vs. 1,548 m), courtesy of the Turkish State Meteorological Service (TSMS, 2020).

Site-specific bioclimatic variables such vegetative and reproductive phase rainfall were calculated from these data by defining when plants typically emerged, flowered and matured at each collection site using observation and local feedback crosschecked against seasonal rules imposed on the monthly climate data, and details were given by Upadhyaya et al. (2011).

\section{Identification}

Cicer turcicum specimens were compared with the species with the closest resemblance (Cicer pinnatifidum and C. judaicum) and with specimens at Akdeniz University herbarium. All parts of the specimens were recorded using a ruler with $0.5 \mathrm{~mm}$ precision. Photographs were taken with a Sony Alpha 700 digital camera.

${ }^{1}$ http://www.worldclim.org

${ }^{2}$ http://www.cru.uea.ac.uk/cru/data/hrg/

\section{Taxonomic Treatment}

According to results of the assessment of morphological including description and habitat with its ecology and molecular data on ITS sequences, the new species were taxonomically classified and evaluated. Also, it was compared to the related species including C. pinnatifidum, C. judaicum, C. echinospermum, and C. reticulatum.

\section{Conservation Status}

Conservation status was suggested according to plant population and the IUCN threat category (IUCN, 2014).

\section{DNA Extraction, PCR, and Sequencing}

Cicer arietinum (ILC 8262 and ICC 8617), C. reticulatum (AWC 602), C. turcicum, C. pinnatifidum (AWC 503 and AWC 505), C. judaicum (PI 458559) and C. cuneatum were grown under controlled conditions in greenhouse for molecular analysis.

Fresh leaves were stored at $-20^{\circ} \mathrm{C}$ until DNA extraction. Total genomic DNA was extracted using the CTAB method of Doyle and Doyle (1990). DNA concentrations were estimated on 1\% agarose gels stained with ethidium bromide. For this study, the nuclear ribosomal internal transcribed spacer region (ITS1, 5.8S rDNA and ITS2) was used to evaluate the relationships between species. The ITS region was amplified using primers ITS 4 and ITS 5 (White et al., 1990). The PCR analysis was carried out with $1 \mathrm{U}$ of Taq DNA polymerase (Fermentas Life Sciences, Burlington, ON, Canada) in the supplied reaction buffer, $2 \mathrm{mM}$ $\mathrm{MgCl}_{2}, 0.2 \mathrm{mM}$ of each dNTP, $0.4 \mu \mathrm{M}$ of each primer and $40 \mathrm{ng}$ of template DNA, and $\mathrm{ddH}_{2} \mathrm{O}$ to a final volume of $15 \mu \mathrm{L}$. PCR amplification conditions were as follows: an initial predenaturation step at $94^{\circ} \mathrm{C}$ for $5 \mathrm{~min}, 35$ cycles of $1 \mathrm{~min}$ at $94^{\circ} \mathrm{C}$, $1 \mathrm{~min}$ at $50^{\circ} \mathrm{C}, 1 \mathrm{~min}$ at $72^{\circ} \mathrm{C}$, and a final extension step of $10 \mathrm{~min}$ at $72^{\circ} \mathrm{C}$. Amplification was performed on a Bioneer thermocycler $\left(\mathrm{MyGenie}^{\mathrm{TM}}\right)$. PCR products were electrophoresed on a $1.5 \%$ agarose gel run at $75 \mathrm{~V}$ in $1 \times$ TAE buffer and visualized under UV light after staining with ethidium bromide. Sequencing was carried out at Macrogen Inc., Europe via BM Laboratories Ltd., with direct sequencing in both directions using the amplification primers. All sequences were manually edited using Chromas v. 2.6.5 (McCarthy, 1996-1998) and aligned in Bioedit v. 7.0.5.3 (Hall, 1999). Double peaks were represented by IUPAC ambiguity codes in the species of $C$. turcicum in the alignment. Sequences were submitted to GenBank.

\section{Screening for Heat Tolerance}

Cicer turcicum phenology and heat tolerance was compared against a range of wild and domestic Cicer accessions (Table 1) in a common garden experiment at the Akdeniz University campus Antalya, Turkey ( $30^{\circ} 44^{\prime} \mathrm{E}, 36^{\circ} 52^{\prime} \mathrm{N}, 51 \mathrm{~m}$ asl). The experiment was conducted in a screenhouse, with plants sown directly into the loam soil for 2 years from 2018-2019 to 20192020. Soil properties were given by Kivrak et al. (2020). Water holding capacity, organic matter, soil nitrogen, zinc, and iron were determined to be at low levels, $\mathrm{CaCO}_{3}$ and $\mathrm{pH}$ were, 26.5 and $7.69 \%$. The experimental design was RCBD with three replications using plots $2 \mathrm{~m}$ in length with row spacing of 
$100 \mathrm{~cm}$, sown on 27th December 2018 in the first year and 29th December 2019 in the second year in order to expose the plants to heat stress during their reproductive phase. Plant phenology (flowering, podding, maturity) was observed at 2-3 day intervals and accessions screened for heat tolerance using a visual 1-9 scale at podset (Table 2). Plants were irrigated with drip irrigation system at 3-day intervals in order to prevent the confounding effects of drought.

\section{Screening for Resistance to the Bruchid}

Callosobruchus chinensis L. maintained at the Department of Plant Protection, Akdeniz University, Antalya, Turkey were used in a no-choice test after Erler et al. (2009) and Eker et al. (2018). Insect rearing was carried out with susceptible chickpea seeds at $26 \pm 2{ }^{\circ} \mathrm{C}$ and $65 \pm 5 \% \mathrm{RH}$ in complete darkness. To rear fresh adults of a uniform age, seeds with eggs were put in clean jars filled with a large number of chickpea seeds which were checked every day for insect health.

Ten seeds of an accession each of C. arietinum, C. pinnatifidum, C. judaicum, and two accessions of C. turcicum (Table 1) were placed in a separate glass jar of one liter. For each accession, three replications were used. Ten pairs (10ㅇ and 10 $\circ^{x}$ ) of day-old adults of the brichid were put into each jar. Then glass jars were covered with a gauze cloth in order to anticipate the flight of the insects and to allow air circulation. The bruchids were forced to feed only the seeds of one accession in a jar. After a week oviposition, the adult insects were carefully removed from each jar. Oviposition in each jar was controlled using a stereo-microscope and number of eggs laid by the insect were counted for each accession separately. The jars were controlled daily for adult emergence for 30 days.

Assessment for resistance to the pulse bruchid was evaluated by recording number of eggs per seed, number of holes per seed, percentage of seed damage and seed weight loss in each accession in no-choice test. The number of eggs per seed was recorded with the stereo-microscope. The number of holes was assessed by the round holes with the "flap" on seed coat. Percentage of seed damage was counted as the damaged seeds for each accession, and then data were converted into percentage as damage incidence according to Khattak et al. (1995):

$$
\begin{gathered}
\text { Damage incidence }(\%)= \\
(\text { No of seeds damaged/Total no of seeds }) \times 100
\end{gathered}
$$

The damage incidence was classified according to Table 2. A similar scale in Cicer and Pisum species was successfully used by Eker et al. (2018) and Esen et al. (2019), respectively. Seed weight loss was determined the following formula (Khattak et al., 1995):

$$
\text { Total loss }(\%)=\left(n_{2}-n_{1}\right) / n_{2} 100,
$$

where $n_{2}$ and $n_{1}$ are the initial weight of seeds before the test and the weight of the damaged seeds after the test, respectively.

\section{Data Analyses}

The phylogenetic tree was constructed with the Maximum Parsimony (MP) method using MEGA v. 7 (Kumar et al., 2018),

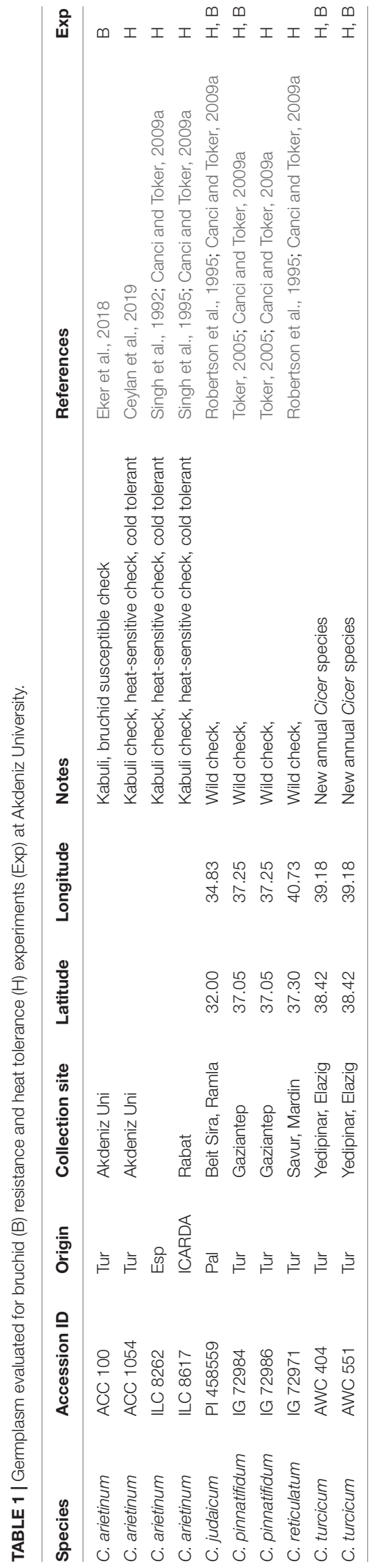


TABLE 2 | A visual quantitative 1-9 scale for resistance to a/biotic stresses evaluated in Exps 1 and 2.

\begin{tabular}{|c|c|c|c|}
\hline Scale & Reaction category & Heat tolerance & Resistance to bruchid \\
\hline 1 & Very highly resistant & Very good vigor and $100 \%$ pod setting and filling & Damage incidence is $0 \%$ and no holes observed \\
\hline 2 & Highly resistant & Good vigor and 96-99\% pod filling & Damage incidence is about $2-5 \%$ \\
\hline 3 & Resistant & Good vigor and 86-95\% pod filling & Damage incidence is 6-10\% \\
\hline 4 & Moderately resistant & Moderate vigor and $76-85 \%$ pod filling & Damage incidence is $11-20 \%$ \\
\hline 5 & Moderate & Poor vigor and 51-75\% pod filling & Damage incidence is $21-30 \%$ \\
\hline 6 & Moderately susceptible & Lack of vigor and $26-50 \%$ pod filling & Damage incidence is $31-40 \%$ \\
\hline 7 & Susceptible & Lack of vigor and $11-25 \%$ pod filling & Damage incidence is $41-50 \%$ \\
\hline 8 & Highly susceptible & Lack of vigor and $1-10 \%$ pod filling & Damage incidence is $51-90 \%$ \\
\hline 9 & Very highly susceptible & No flowering or podding & Damage incidence is more than $91 \%$ \\
\hline
\end{tabular}

under heuristic searches with 100 random addition sequence replicates and tree-bisection-reconnection (TBR) branch swapping, saving no more than 100 trees with length $\geq 1$ per replicate, automatically increasing the maximum number of trees saved. Bootstrapping was performed using the same settings and 1,000 replicates, but without branch swapping. For the phylogenetic analyses, available sequences of $C$. echinospermum (AB198910.1) and C. bijugum (AJ237701.1) were retrieved from GenBank for comparison. Also, the sequences data belongs to P. sativum L. (L36637.1) and L. culinaris Medik. subsp. orientalis (Boiss.) Ponert (AJ441321.1) were used as outgroups in the phylogenetic analyses.

Visual scale data were converted to percentage and then used to perform analysis of variance (ANOVA) using Genstat V20 software, nesting accessions within species. Residual plots were generated to detect errors and confirm common and independent variance. For each stressor, significant differences between the accessions were studied using LSD and Duncan multiple range tests.

\section{RESULTS}

\section{Collection of $\boldsymbol{C}$. turcicum}

Plant specimens and mature seeds were collected near Yedipinar collection site in the Sivrice district (Elazig Province, Turkey) on 12th June 2015 (Figure 1). Plants were flowering and podding, with some mature pods (Figure 2).

Cicer turcicum appears to be a rare species, found only once among the 242 sites surveyed in Turkey, Armenia and Georgia (Table 3). The Yedipinar collection site is remote from other known occurrence of annual wild Cicer (Figure 1b), $38 \mathrm{~km}$ from the closest C. pinnatifidum, $46 \mathrm{~km}$ from C. reticulatum, $49 \mathrm{~km}$ from C. echinospermum, and $124 \mathrm{~km}$ from C. bijugum.

\section{Species Biology and Habitat Characterization}

Cicer turcicum is an East Anatolian endemic in the IranoTuranian phytogeographic region. Habitat is a hilly area with some trees cover on the slopes ranging from isolated oak woodlands, oak/juniper forest and some pine plantations. The plants were located in a tight cluster in a light brown sandy loam on a S-facing rubble slope adjacent to the Sivrice-Gozeli road

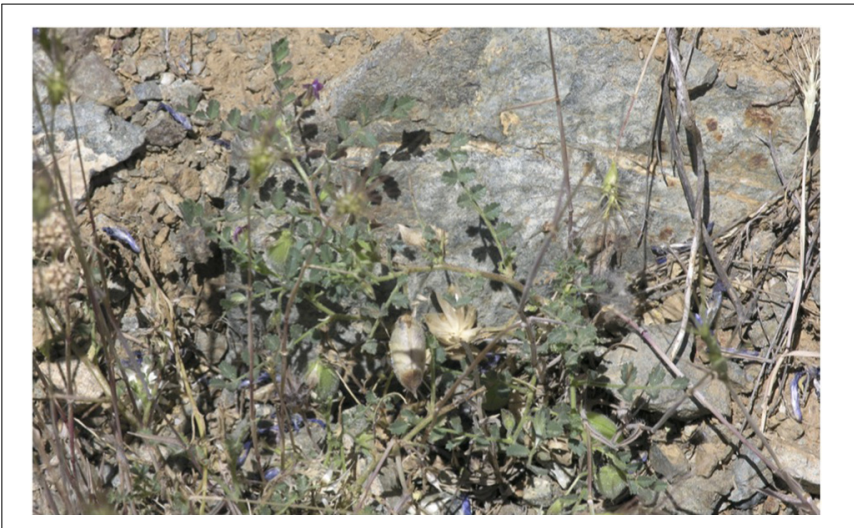

FIGURE 2 | C. turcicum in situ at Yedipinar collection site, Sivrice district, Elazig province, Turkey on 12th June 2015. Specimen is both flowering and podding, with some mature pods.

TABLE 3 | Number of survey sites in which wild Cicer species were found, categorized by country and species.

\begin{tabular}{|c|c|c|c|c|}
\hline Country & Armenia & Georgia & Turkey & Total \\
\hline Total survey sites & 25 & 8 & 209 & 242 \\
\hline \multicolumn{5}{|c|}{ Annual wild Cicer species } \\
\hline C. reticulatum & & & 40 & 40 \\
\hline C. echinospermum & & & 18 & 18 \\
\hline C. bijugum & & & 7 & 7 \\
\hline C. pinnatifidum & & & 38 & 38 \\
\hline C. turcicum & & & 1 & 1 \\
\hline \multicolumn{5}{|c|}{ Perennial wild Cicer species } \\
\hline C. anatolicum & 1 & & 4 & 5 \\
\hline C. isaricum & & & 1 & 1 \\
\hline
\end{tabular}

$(38.4174 \mathrm{~N}, 39.1783 \mathrm{E})$ in moderately dense annual vegetation at 1,544-1,553 m elevation (Figure 1c).

Based on in-situ field observation made during the Cicer survey and collection mission, C. turcicum phenology seems most similar to $C$. reticulatum and somewhat later than C. pinnatifidum. Most of the latter species observed close to the Yedipinar collection site had mature, shattered pods at this time (see also subsequent phenology data from common garden comparison). On this basis we expect $C$. turcicum to germinate 
TABLE 4 | Characteristics of the sole C. turcicum collection site at Yedipinar village, Sivrice district, Elazig province, Turkey based on geographic data extracted from Garmin Montana 650 and climate data from WorldClim (Hijmans et al., 2005) and 10 min Climatology (New et al., 2002), calculated over the indicated growing season phases.

\begin{tabular}{|c|c|c|c|c|c|}
\hline Descriptor & Site mean & Pre-season (July-Oct) & Veg phase (Oct-May) & Rep phase (May-June) & Season total \\
\hline Latitude $\left({ }^{\circ} \mathrm{d}\right)$ & 38.4175 & & & & \\
\hline Longitude $\left({ }^{\circ} \mathrm{d}\right)$ & 39.1782 & & & & \\
\hline Elevation (m) & 1548 & & & & \\
\hline Mean temp $\left({ }^{\circ} \mathrm{C}\right)$ & & & 3.9 & 17.1 & 6.8 \\
\hline Min temp $\left({ }^{\circ} \mathrm{C}\right)$ & & & -6.6 & & \\
\hline Max temp $\left({ }^{\circ} \mathrm{C}\right)$ & & & & 26.0 & \\
\hline Temp change ( ${ }^{\circ} \mathrm{C} /$ day $)$ & & & & 0.1 & \\
\hline Frost days (sum) & & & 94 & 1 & 94 \\
\hline Precipitation (sum, mm) & & 15 & 554 & 88 & 642 \\
\hline Precipitation CV (\%) & & & 59 & 81 & 64 \\
\hline Rain days (sum) & & & 82 & 17 & 98 \\
\hline Rel humidity (\%) & & & 66 & 44 & 61 \\
\hline Sun hrs (\%/day) & & & 52 & 75 & 58 \\
\hline
\end{tabular}

with the opening autumn rains (October), start flowering in late April/early May and mature from mid-June onward like other annual Cicer species. Climate at the collection site of C. turcicum is typically Mediterranean, with arid summers and cold winters. The area is relatively cool, with snow cover 5 months of the year, reflecting the relatively high elevation (Table 4). Accordingly, C. turcicum receives most of its seasonal rainfall during the vegetative phase, characterized by frequent, reliable precipitation, high relative humidity, and low sunshine (Table 4 and Figures 3A,B). Vegetative mean temperatures are very low and there is a high incidence of frost (Table 4). The mean reproductive phase climate is mild, with relatively low temperatures, a low rate of temperature increase, and relatively frequent rainfall (Table 4). Monthly mean temperatures from climate databases do not capture the climatic extremes that are likely to exert strong selection pressure on endemic plant species. This is demonstrated by data from the nearby (albeit considerably lower altitude) Elazig airport weather station which shows that temperatures can range from $<-20^{\circ} \mathrm{C}$ to $>40^{\circ} \mathrm{C}$ in the vegetative and reproductive phases, respectively (Figure 3A). Given the much greater elevation of the Yedipinar collection site, it is likely that minimum temperatures may range even lower than this, while reproductive phase temperatures may not be as extreme.

\section{Taxonomy-Morphology of C. turcicum Description}

Annual; stem semi-prostrate up to $45 \mathrm{~cm}$ long, procumbent branches at base, completely pubescent, glandular hairs. Leaves imparipinnate with 7 pairs of leaflets; rachis $3-5 \times 0.7-1.1 \mathrm{~cm}$ in outlines; petiol 5-6 mm; leaflets pubescent, fairly close, opposite or not, shortly petiolulate $0.5 \mathrm{~mm}$, oblong-elliptic, 5$6(-7) \times 2-4 \mathrm{~mm}$, and a single leaflet at base of rachis (arrow in Figures 4a,e), basal 1/5 part entire; teeth 9-11 (-14), acute. Stipules pubescent, four unequal teeth, each teeth triangular, 2$3 \times 4-6 \mathrm{~mm}$ (Figure 4b). Inflorescence generally 1-flowered (seldom double-flowered), axillary racemes; peduncle pubescent,
4-10 $\mathrm{mm}$, ending in an arista, $2 \mathrm{~mm}$; bracts linear, $0.5 \mathrm{~mm}$; pedicel pubescent, $4-8 \mathrm{~mm}$. Calyx hardly dorsally gibbous at the base, pubescent, 3-6 $\mathrm{mm}$, teeth triangular-lanceolate, 2-4 $\mathrm{mm}$. Corolla veined, glabrous, purple-magenta, fading into blueviolet and magentaroadly ovate, when old; standard (wexillum), emarginated at apex, attenuate at base, $8-10 \times 6-8 \mathrm{~mm}$; wings (alae) obovate, strongly auriculate at base, 6-7 $\times 2-3 \mathrm{~mm}$; keel (carina) rhomboid, 4-5 × 1.5-2.5 mm. Stamens diadelf $(9+1)$, filaments 5-6 mm long (fused part $4 \mathrm{~mm}$, free part $1.5-2 \mathrm{~mm}$, upturned). Ovary ovoid, $6 \mathrm{~mm}$ long, densely glandular pubescent; style ca. 2-4 mm, upturned. Pods rectangular ovate at base, 15$18 \times 6-9 \mathrm{~mm}$, stylus and stamens persistent when old, 3-4 seeds, shattered when ripe. Seeds triangular-arietinoid, distinctly bilobular, beaked, 5-6 × 4-5 mm, hilum 0.5-1 mm, seed coat greenish-dark brown, tuberculated (Figures 4c,d).

Cicer turcicum is completely different from C. pinnatifidum, C. judaicum, C. echinospermum, and C. reticulatum because of gross morphology and seed size/shape differences (Figure 4 and Table 5). Flowers, pods and seeds of the new species are larger than those of $C$. pinnatifidum and C. judaicum, while they were smaller than those of $C$. echinospermum and $C$. reticulatum (Table 5). The new species can easily be distinguished by differences in leaflets (one of leaflets at the base of leaf is single), stipules (Crown-shaped), and seeds (greenish-dark brown and tuberculate) from C. pinnatifidum, C. judaicum, C. echinospermum, and C. reticulatum (Figure 4).

\section{Taxonomic Treatment}

Based on morphological and molecular data allowing comparison to the related samples, it was decided that the specimens collected from Elazig belongs to a new species. This species was named C. turcicum and taxonomically put in subgenus Pseudononis M. Pop. and section Cicer M. Pop. (van der Maesen et al., 2007; Ozturk et al., 2013).

Cicer turcicum Toker, Berger \& Gokturk, sp. nov. (Figures 4a-d).

Type: -TURKEY. B7 Elazig: Sivrice, Yedipinar around $(38.4174 \mathrm{~N}, 39.1783 \mathrm{E})$ at $1,544-1,553 \mathrm{~m}$ elevation, in June 2015, 


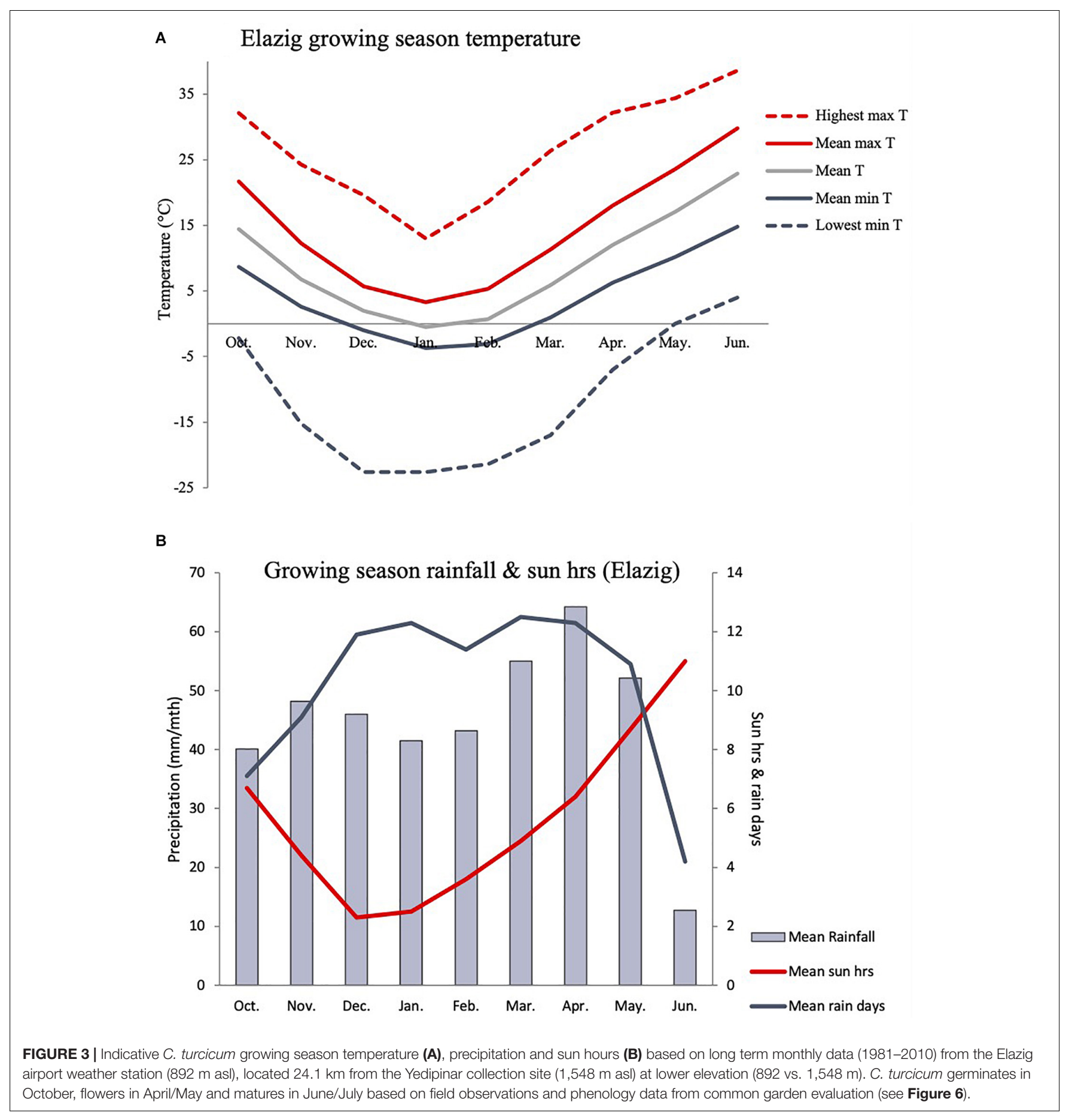

Toker, Berger (1001) \& Gokturk (holotype Akdeniz University herbarium!, isotypes PAMUH!, ANK!, HUB!, GAZI!).

\section{Etymology}

The specific epithet is derived from the name of Turkey.

\section{Alignment and Sequence Characteristics}

Nucleotide sequences were deposited in GenBank (accessions MW424513-MW424518). The ITS region (ITS1-5.8S gene-ITS2) in Cicer ranged from 692 to 704 bp. The aligned length for the ITS dataset was 662 positions, with 58 informative sites and 118 variable sites. In total, 43 diagnostic single nucleotide polymorphisms and one tri-nucleotide deletion were observed in the aligned dataset. No intraspecific variation was observed in C. arietinum, C. turcicum, and C. pinnatifidum. C. turcicum showed seven single nucleotide identities to the sequences of C. arietinum, C. reticulatum, and C. echinospermum (Table 6), positions: $(45,78,103,204,457,472,474)$. This species had 

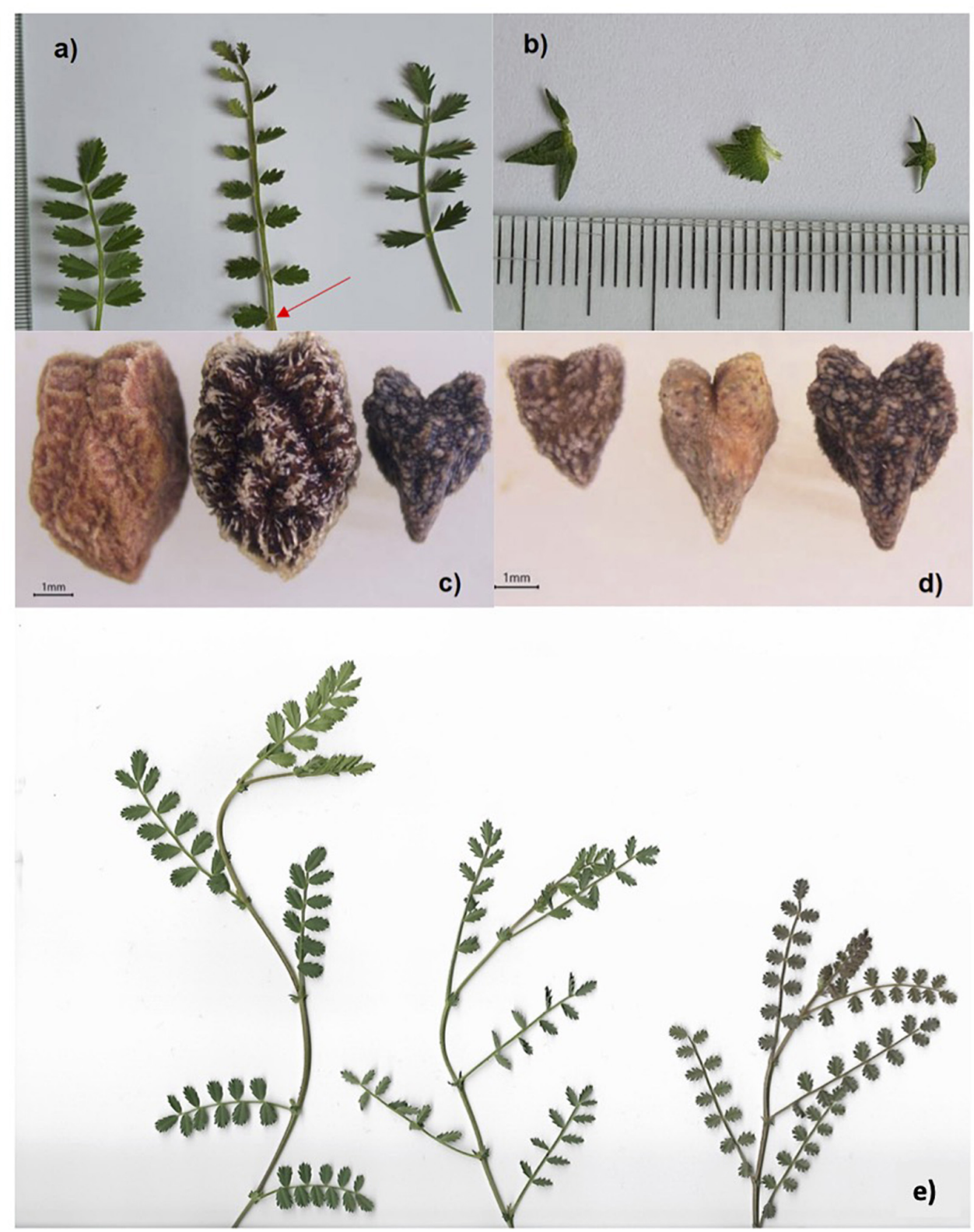

FIGURE 4 | Leaves of C. pinnatifidum, C. turcicum and C. judaicum (a, left to right). Single leaflet at the base of leaves of $C$. turcicum (red arrow). Stipules of C. judaicum, C. pinnatifidum, and C. turcicum (b, left to right). Seeds of C. reticulatum, C. echinospermum, and $C$. turcicum (c, left to right). Seeds of $C$. judaicum, C. pinnatifidum, and C. turcicum (d, left to right). Shoots of C. pinnatifidum, C. judaicum, and C. turcicum (e, left to right).

an identical nucleotide with $C$. pinnatifidum in the position of 98. Additionally, their three nucleotide deletions (GAC, position: 205-207) were shared. C. turcicum had double peaks in direct sequences, so additive characters were represented in the positions of 536 and 588 (Table 6). These characters were not observed in any other species.

\section{Phylogenetic Analysis of the ITS Region}

The MP analysis resulted in 10 equally parsimonious trees (length: 133) with a consistency index (CI) of 0.898, a retention index (RI) of 0.917 and a rescaled index (RC) of 0.868 . In the phylogenetic tree, four major groups were observed (Figure 5), one of which included $P$. sativum and L. culinaris subsp. orientalis as out-group, while the rest were taxa in the genus Cicer. Group I, consisting of C. arietinum, C. reticulatum, C. echinospermum, and $C$. turcicum, was supported by a $98 \%$ bootstrap value in the parsimony tree. This group revealed two subgroups (Figure 5). There was a strong support that $C$. turcicum was in the different group from $C$. arietinum, C. reticulatum, C. echinospermum (bootstrap support, 99\%). Group II included C. pinnatifidum, C. bijugum, and C. judaicum. This group showed a bootstrap value of $98 \%$. Group III only consisted of C. cuneatum. 
TABLE 5 | Comparison of C. turcicum for diagnostic characteristics with C. pinnatifidum, C. judaicum C. echinospermum, and C. reticulatum.

\begin{tabular}{|c|c|c|c|c|c|}
\hline Characteristics & C. judaicum* & C. pinnatifidum* & C. turcicum & C. echinospermum* & C. reticulatum ${ }^{\star * *}$ \\
\hline Leaves (no) & $(7-9) 11-13$ & $4-9(11)$ & $13-14$ & $7-11$ & $8-15$ \\
\hline Leaflets (mm) & $4-7(9) \times 2-5(8)$ & $4-11(12) \times 2-5(7)$ & $5-6(7) \times 2-4$ & $4-9(11) \times 2-5$ & $5-11(15) \times 2-4$ \\
\hline Stipules (no of teeth) & 3 & $6-7$ & 4 & $3-5$ & $4-5$ \\
\hline Seeds (mm) & $3-4 \times 3-4$ & $4-6 \times 3-5$ & $5-6 \times 4-5$ & $7 \times 5$ & $5-9 \times 4-6$ \\
\hline Pods (mm) & $10-13 \times 5-6$ & $10-15 \times 6-8$ & $15-18 \times 6-9$ & $15-20 \times 10-12$ & $12-16 \times 8-12$ \\
\hline Leaflet position & Opposite or not & Opposite or not & $\begin{array}{c}\text { Opposite or not but a single } \\
\text { leaflet at base }\end{array}$ & Opposite or not & Opposite or not \\
\hline Distribution** & Levant (Isr, Pal, Leb, Syr) & Levant, S \& SE Anatolia & E Anatolia (1 location) & SE Anatolia & SE Anatolia \\
\hline
\end{tabular}

*, **, and *** Data were obtained by van der Maesen (1972); Berger et al. (2003), and Ladizinsky (1975), respectively.

TABLE 6 | Species diagnostic differences in ITS region.

Species

Position in alignment

\begin{tabular}{|c|c|c|c|c|c|c|c|c|c|c|c|}
\hline & 45 & 78 & 98 & 103 & 204 & 205-207 & 457 & 472 & 474 & 536 & 588 \\
\hline C. arietinum & A & C & $A$ & $\mathrm{C}$ & $\mathrm{T}$ & GAC & $G$ & $\mathrm{C}$ & $\mathrm{T}$ & $\mathrm{T}$ & $A$ \\
\hline C. reticulatum & A & $\mathrm{C}$ & A & $\mathrm{C}$ & $\mathrm{T}$ & GAC & G & C & $\mathrm{T}$ & $\mathrm{T}$ & A \\
\hline C. echinospermum & $A$ & $\mathrm{C}$ & $A$ & $\mathrm{C}$ & $\mathrm{T}$ & GAC & $G$ & C & $\mathrm{T}$ & $\mathrm{T}$ & A \\
\hline C. turcicum & A & C & $\mathrm{G}$ & C & $\mathrm{T}$ & GAC & G & C & $\mathrm{T}$ & $\mathbf{Y}^{*}$ & $\mathbf{R}^{*}$ \\
\hline C. judaicum & C & $\mathrm{T}$ & A & - & G & - & A & $\mathrm{T}$ & C & $\mathrm{T}$ & $A$ \\
\hline C. pinnatifidum & C & $\mathrm{T}$ & $G$ & - & $G$ & - & $A$ & $\mathrm{~T}$ & C & $\mathrm{T}$ & $A$ \\
\hline C. cuneatum & $\mathrm{C}$ & $\mathrm{T}$ & A & - & G & - & $A$ & $\mathrm{~T}$ & C & $\mathrm{T}$ & A \\
\hline C. bijugum & C & $\mathrm{T}$ & $A$ & - & $G$ & - & $A$ & $\mathrm{~T}$ & $\mathrm{C}$ & $\mathrm{T}$ & $A$ \\
\hline
\end{tabular}

*Additive characters (double peaks in direct sequences) are represented by IUPAC codes in bold.

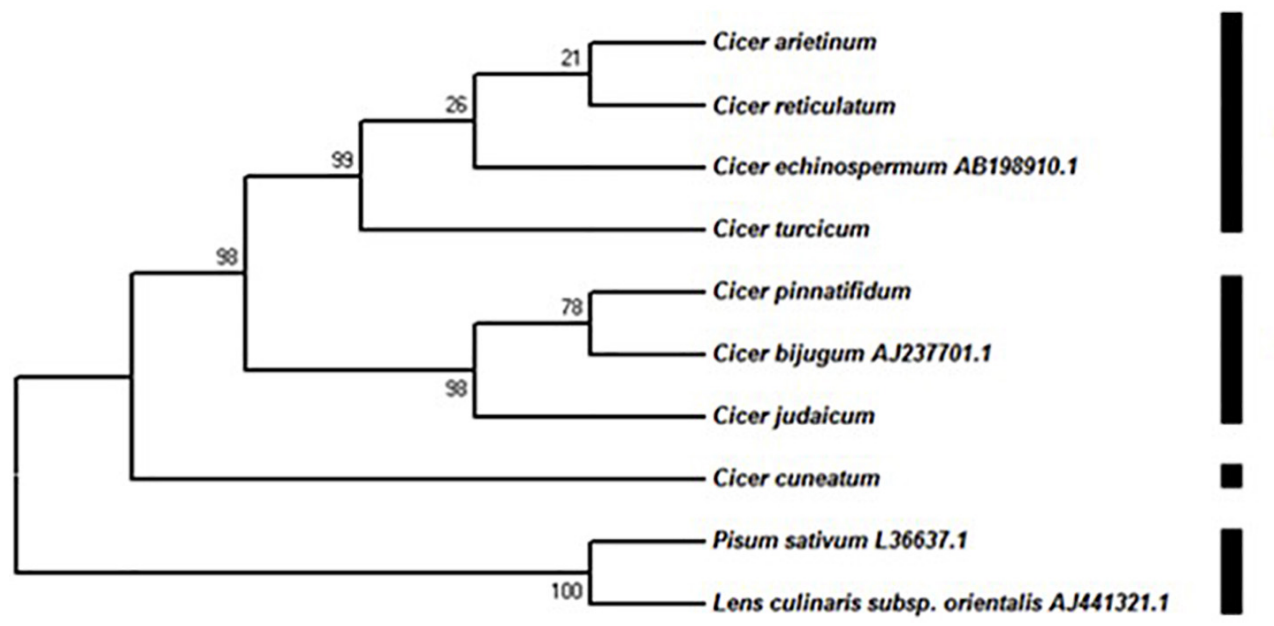

Group I

Group II

Group III

Group IV / Outgroup

FIGURE 5 | Phylogenetic tree from the maximum parsimony analysis based on the sequence of ITS region in Cicer taxa.

\section{Phenology}

Common garden evaluations in the Akdeniz University screenhouse in 2018/19 and 2019 confirmed field observations made at the Yedipinar collection site regarding the typical Mediterranean winter annual phenology of C. turcicum. In the 2018/19 experiment, C. turcicum flowered and podded slightly later than $C$. reticulatum, followed by the remaining annual wild Cicer species, while in the following year there were no significant differences among any of the annual wild Cicer species (Figure 6). Domestic chickpea covered a wider range, the cultivar Ompar and ILC 8262 returning intermediate flowering and podding dates, while ILC 8617 was consistently 7-10 days later in both years (Figure 6, $P<0.001$ ). C. turcicum matured relatively early, particularly in the 2019/20 experiment, where it was earlier than C. judaicum, an accession of C. pinnatifidum and particularly C. reticulatum (Figure 6). In 2018/19, wild Cicer maturity was more evenly distributed, with only C. reticulatum maturing at a later date than the rest of the group. C. arietinum 

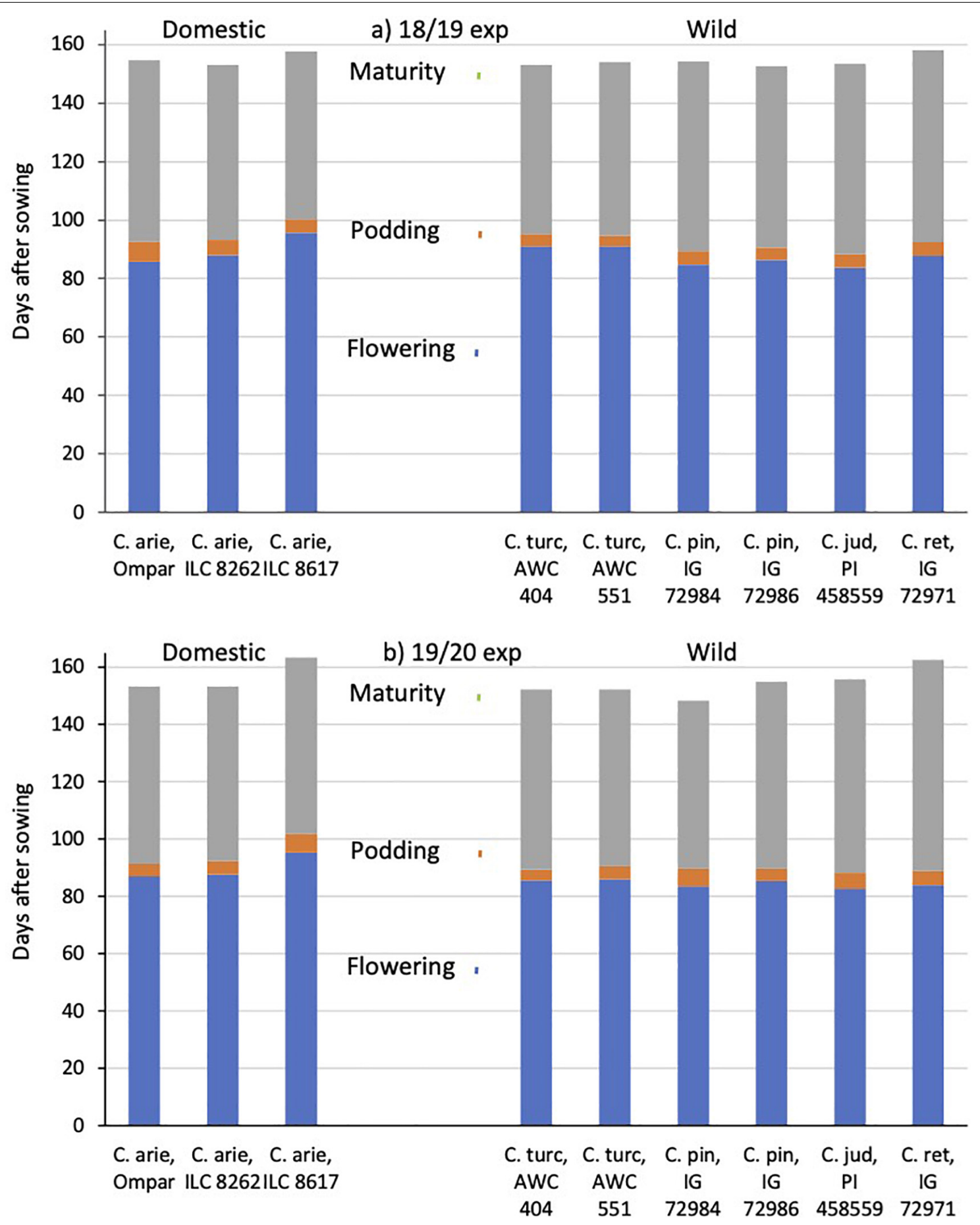

FIGURE 6 | C. turcicum phenology (flowering, podding, maturity) compared to related annual wild and domestic Cicer species. Data is from Mediterranean cool-season common garden screenhouse comparisons at Akdeniz University, (a) 2018/19, (b) 2019/20. Color-coded vertical lines represent accession least significant differences (LSD $P<0.05)$ for flowering (2.6-2.7 days), podding (2.4-2.7 days) and maturity (1.9-2.4 days). Abbreviations: C. arie, C. arietinum; C. turc, C. turcicum; C. pin, C. pinnatifidum; C. jud, C. judaicum; C. ret, C. reticulatum.

maturity dates followed the other phenological data, Ompar and ILC 8262 maturing early (similar to C. turcicum), +while ILC 8617 was consistently 3-10 days later (Figure 6, similar to C. reticulatum).

\section{Heat Tolerance}

Despite the broad phenological similarities described above (Figure 6), there were dramatic differences in pod setting under elevated reproductive phase temperatures between wild 
A Pod set (\%) in glasshouse (2018/19 exp)

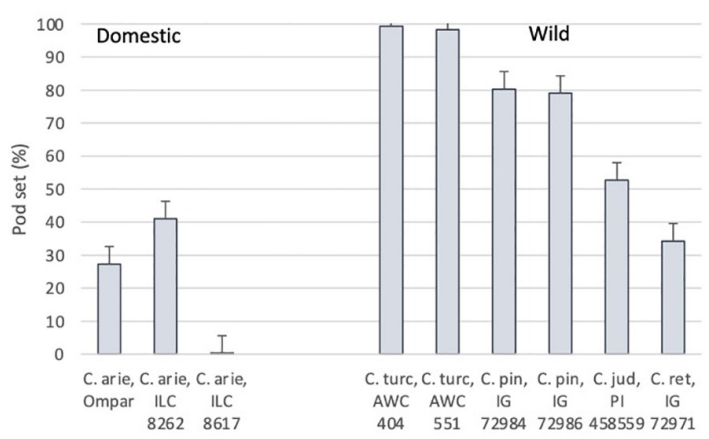

C 50

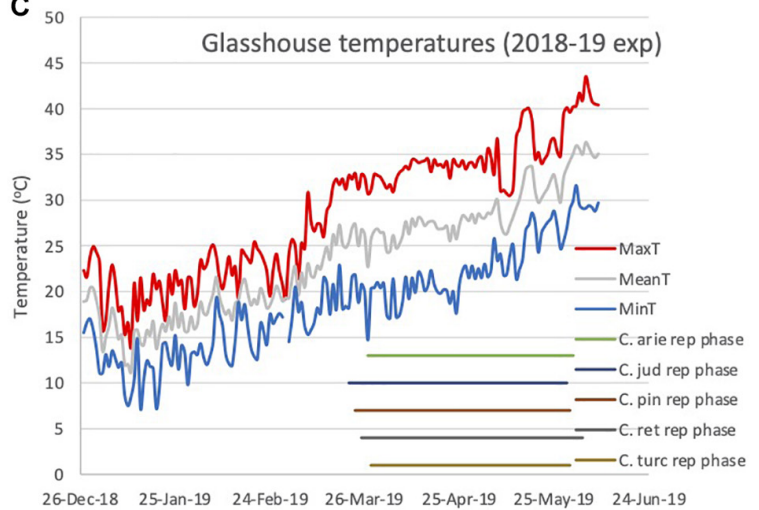

B Pod set (\%) in glasshouse (2019/20 exp)

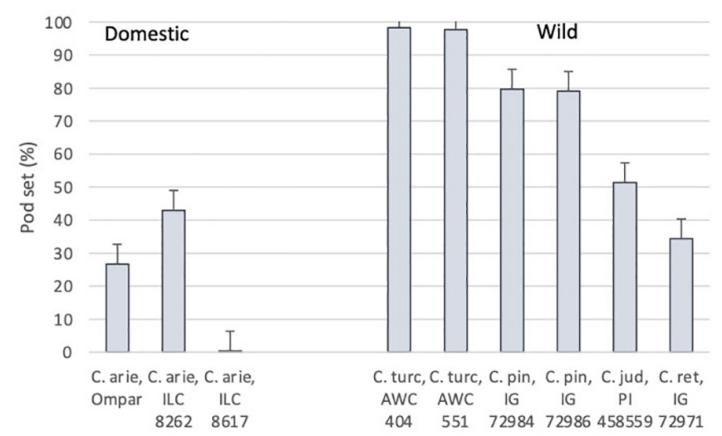

D 5

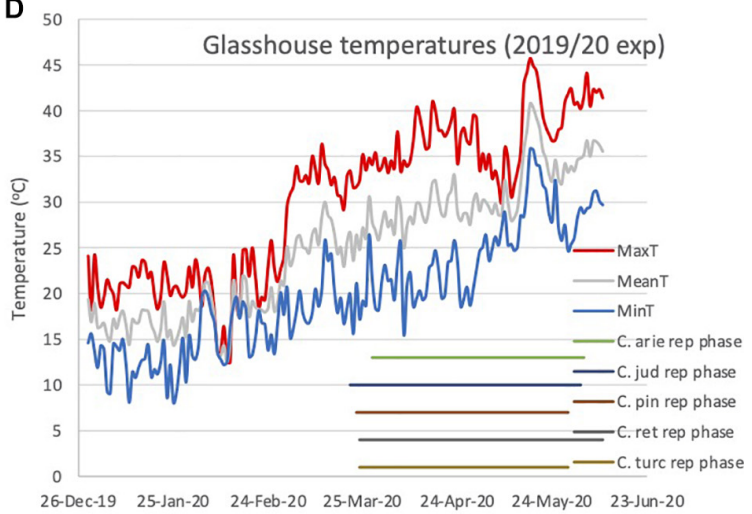

FIGURE $7 \mid$ C. turcicum pod set percentage $(\mathbf{A}, \mathbf{B})$ under high reproductive phase temperatures (C,D) compared to related annual wild and domestic Cicer species. Data is from Mediterranean cool-season common garden screenhouse comparisons at Akdeniz University, (A,C) 2018/19, (B,D) 2019/20. Error bars represent accession least significant differences (LSD $P<0.05$ ). Reproductive phase lengths (flowering to maturity) are shown individually for each species (B). Abbreviations: C. arie, C. arietinum; C. turc, C. turcicum; C. pin, C. pinnatifidum; C. jud, C. judaicum; C. ret, C. reticulatum.

and domestic Cicer species in both years (Figure 7). ANOVA indicated large species differences across years $(P<0.001)$, without interaction $(P<0.574)$, and smaller differences between varieties within species $(P<0.001)$, again without interaction over years. Thus, while pod set percentage means of all wild Cicer species were greater than in domestic chickpea $(P<0.001)$, C. turcicum $>$ C. pinnatifidum $>$ C. judaicum $>$ C. reticulatum (Figures 7A,B $P<0.05$ ). Pod set in domestic chickpea germplasm varied from $0 \%$ in ILC 8617 to $43 \%$ in ILC 8262, the latter variety setting a greater proportion of pods than IG $72971(P<0.05)$, the sole representative of $C$. reticulatum in this experiment. Analysis of the diurnal temperatures ranges recorded during the experiment demonstrated that heat escape resulting from variable phenology was not a factor in these inter-specific differences (Figures 7C,D). Mean temperatures increased linearly throughout the reproductive phase $(2018 / 19$, $0.11^{\circ} \mathrm{C} /$ day, $r^{2}=0.71 ; 2019 / 20,0.13^{\circ} \mathrm{C} /$ day, $\left.r^{2}=0.62\right)$ from ca. $26^{\circ} \mathrm{C}$ at flowering to $>35^{\circ} \mathrm{C}$ at maturity (Figures $7 \mathrm{C}, \mathrm{D}$ ). While temperature maxima fluctuated more on a daily basis, with weaker linear trends $\left(2018 / 19,0.09^{\circ} \mathrm{C} /\right.$ day, $r^{2}=0.49 ; 2019 / 20$, $0.10^{\circ} \mathrm{C} /$ day, $r^{2}=0.36$ ), all species experienced maxima $>40^{\circ} \mathrm{C}$ during podding in both years, and none escaped sharply rising temperatures toward the end of the growing season in either year (Figures 7C,D).

\section{Resistance to Bruchid}

Orthogonal contrasts revealed striking wild-domestic differences in bruchid resistance, accounting for all of the significant species differences. Seed damage was far lower in wild compared to domestic Cicer, whether measured as the number of holes on the seed coat (Figure 8, $P<0.001$ ), percentage of seeds damaged $(P<0.001)$ or in terms of seed dry matter consumed by the bruchids $(P<0.031)$. As a result, bruchid egg production was far lower on wild compared to domestic Cicer (Figure 8, $P<0.001$ ). There were no significant differences among wild Cicer for any of these traits, nor between the two $C$. turcicum accessions evaluated in the present study $\left(P_{\text {diff }}=0.452-0.976\right)$.

\section{DISCUSSION}

In the present study we introduce $C$. turcicum, a new annual wild Cicer species hitherto unknown to science. C. turcicum appears to be a rare species, thus far recorded only in a single location in Elazig province, SE Anatolia, at a considerable distance from the nearest known wild Cicer population (Figure 1). The Yedipinar collection site has a realtively high elevation (ca $1,550 \mathrm{~m}$ ) and exposes C. turcicum to an extreme temperature range throughout the growing season, from very cold winters 


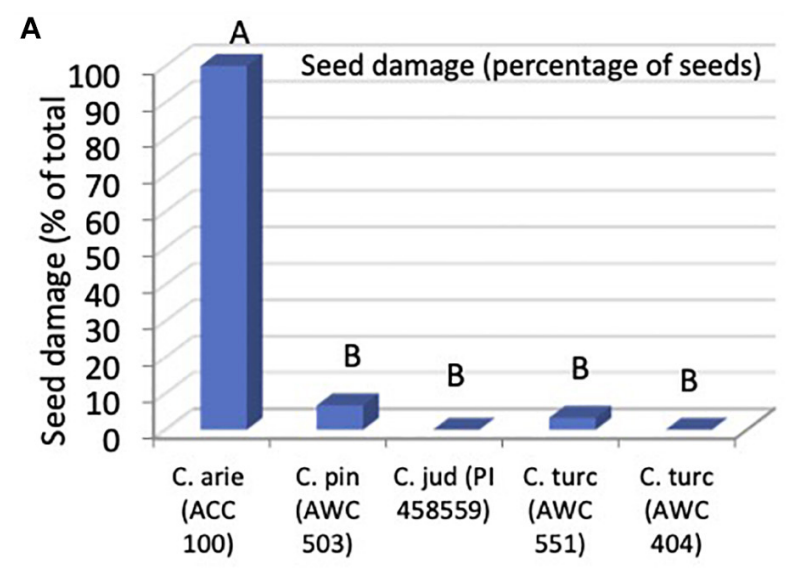

C

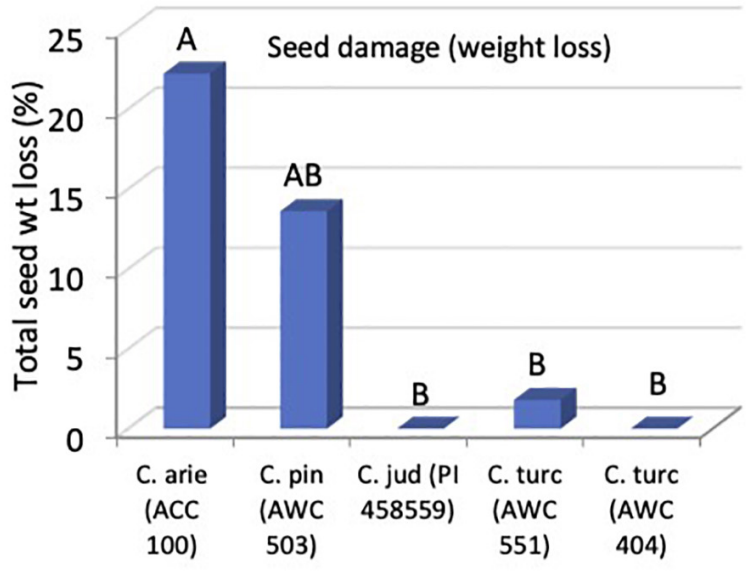

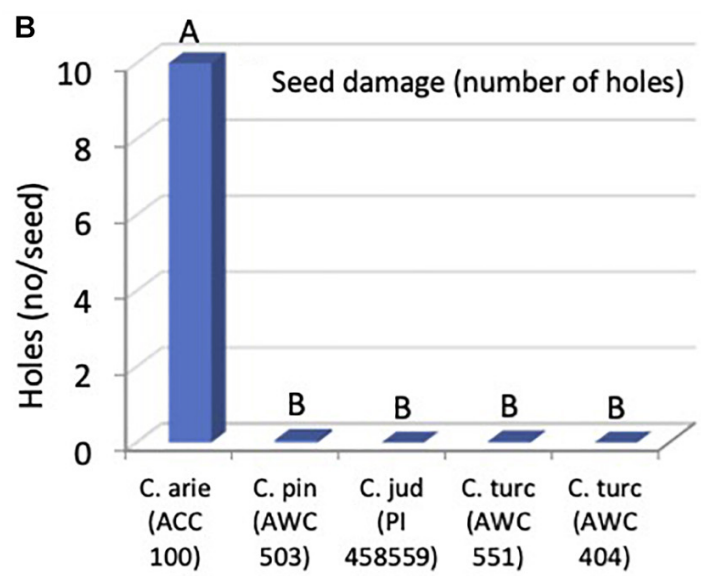

D

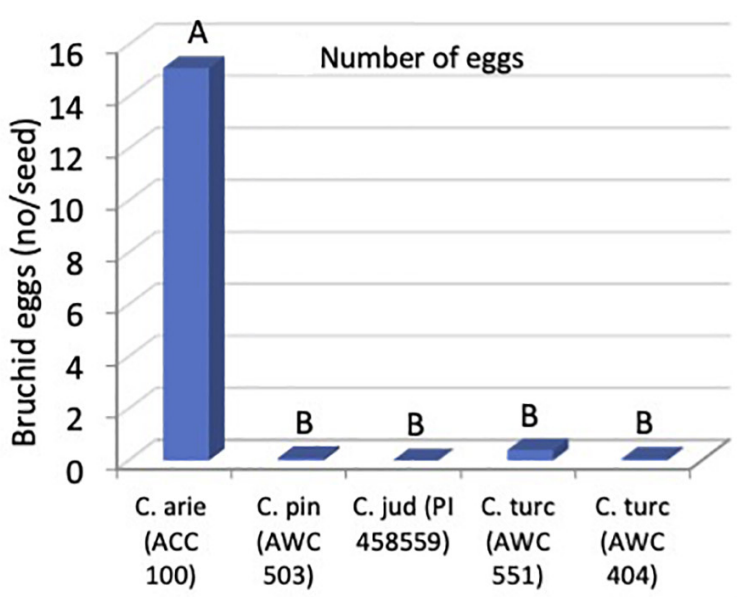

FIGURE 8 | Bruchid resistance in wild compared to domestic Cicer species in terms of seed damage (A), number of holes (B), weight loss (C), and number of eggs (D), from a no-choice feeding test at Akdeniz University. Letters represent accession group membership from Duncan multiple range test, different letters indicate significant difference $(P<0.05)$.

to hot, dry summers. C. turcicum has a distinct morophology that separates it from wild relatives, paticularly leaflet and seed size, distribution and shape (see Figure 4 and Table 5), while ITS sequencing suggests it to be closely related to C. arietinum, C. reticulatum, and C. echinospermum (Figure 5). Common garden evaluation demonstrates that $C$. turcicum has a typical annual wild Cicer phenology, but appears to be more tolerant of reproductive heat stress than its wild relatives, and similarly resistant to bruchid feeding.

These findings raise a number of interesting implications and questions that need to be followed up. Arguably the most important of these is species rarity. The 2013-2018 Cicer mission surveyed 242 sites in detail, geo-referencing the presence/absence of wild crop legume relatives (Cicer, Pisum, Lens) and noting associated species. The fact that $C$. turcicum was only found at a single location underlines its relative scarcity. However, while the region immediately south of the Yedipinar collection site has been comprehensively surveyed (Figure 1), there were very few sites in Elazig province itself, particularly the areas surrounding Yedipinar to the north. A population of C. pinnatifidum was found at Tepekoy, $38 \mathrm{~km}$ to the west of Yedipinar, while Lens was found between Maden and Ergani, $42 \mathrm{~km}$ to the east of Yedipinar. Clearly, there is more work to do to establish the C. turcicum distribution. However, at this stage, with only a single collection site identified, it may be prudent to place C. turcicum under the IUCN threat category "Critically Endangered (CR)" (IUCN, 2014) because its estimated area of occupancy is less than $10 \mathrm{~km}^{2}$, population size is estimated to be less than 50 mature individuals, and is under threat of heavy grazing pressure [CR B2; C2a(i)] given its proximity to Yedipinar and the SivriceGozeli road (Figure 1c). In the meantime, we suggest that further survey missions focusing on Elazig province be undertaken as a matter of urgency.

While the identification of any new species is of in interest in its own right, the fact that C. turcicum is both an annual and appears to be closely related to $C$. arietinum, the single domesticated Cicer species makes it all the more important because annual Cicer species are relatively uncommon and its relatedness to chickpea opens new questions regarding the domestication of this crop. The ITS-sequencing phylogeny 
presented in this study reflects the current taxonomic status of the species. Thus, Pisum and Lens were outgroups, reflecting their status as genera in the tribe Fabeae Rchb. referred to as Vicieae (Schaefer et al., 2012), while all the Cicer species were broadly clustered in Cicereae (Javadi and Yamaguchi, 2004; Schaefer et al., 2012). The within Cicer species clustering closely followed the known genepool (GP) classification:

(1) GP1: C. arietinum (domesticated chickpea) and C. reticulatum (Ahmad, 1999). Hybridization in the primary gene pool (GP1) is straightforward, progeny are fully fertile due to good chromosome pairing, alien gene transfer is achievable from wild to domesticated chickpea with traditional methods (Ladizinsky and Adler, 1976a,b; Adak et al., 2017; Koseoglu et al., 2017).

(2) GP2: C. echinospermum. Species in GP2 can be crossed with domesticated chickpeas and produced at least some fertile progeny, while hybrids are weak, partly sterile, and recovery of progeny in subsequent generations is difficult due to post fertilization problems (Mallikarjuna et al., 2011). Hybridization success varies between accessions (Kahraman et al., 2017). The proximity of C. turcicum to C. echinospermum in the ITS dendrogram (Figure 5) suggests that it is likely to be a member of GP2. To confirm this a hybridization program crossing $C$. turcicum with C. arietinum and C. echinospermum should be established.

(3) GP3. Species in GP3 are difficult to cross successfully with domesticated chickpeas (Ahmad et al., 1988; Badami et al., 1997; Clarke et al., 2006; Abbo et al., 2011) and include C. bijugum, C. judaicum, C. pinnatifidum, and C. cuneatum. Our ITS phylogeny places C. cuneatum in a separate cluster from the other GP3 species, and is in agreement with an earlier RAPD-derived phylogeny (Ahmad, 1999).

The discovery of C. turcicum at a single location in Yedipinar location, Sivrice district, Elazig province underlines the importance of Turkey as a center of biodiversity, particularly of the wild relatives of domesticated crops including chickpea. Turkey includes over $30 \%$ endemic species of approximately 12,000 natural vascular plant taxa in the world including 3,788 endemics (Guner et al., 2012). These are well documented using a grid system (Ture and Bocuk, 2010) and are distributed in different phytogeographical regions that intersect in Anatolia. A total of 17 Cicer taxa including domesticated chickpea, C. anatolicum, C. bijugum, C. echinospermum, C. floribundum var. floribundum, C. floribundum var. amanicola, C. heterophyllum var. heterophyllum, C. heterophyllum var. kassianum, C. insicum subsp. incisum, C. incisum subsp. serpentinica, C. isauricum, C. montbretti, C. pinnatifidum, C. reticulatum, C. oxydon, C. turcicum, and C. uludereensis are known to occur in Anatolia. The distribution of both extant Cicer species and their archeological remains suggest that Anatolia is not only the primary gene center of the genus Cicer, but also the cradle of the genus in terms of species richness.

Finally, the preliminary discovery of heat tolerance and bruchid resistance in $C$. turcicum add value to it's role as a donor in crop improvement should it be readily crossable with chickpea, or as experimental material to study responses to these stresses if it is not readily crossable. Heat stress causes yield loss in chickpea: day temperatures $>32^{\circ} \mathrm{C}$ reduces pod set (Basu et al., 2009). The incidence of heat stress in chickpea is predicted to rise in line with the $2-3^{\circ} \mathrm{C}$ temperature rise expected as a result of climate change in the near future (IPCC, 2007; Hatfield and Prueger, 2015). Although a number of studies have been carried out on heat tolerance in cultivated chickpea (Canci and Toker, 2009b; Krishnamurthy et al., 2011; Upadhyaya et al., 2011; Devasirvatham et al., 2015; Farooq et al., 2017; Paul et al., 2018) and its wild relatives (Canci and Toker, 2009a) yet they have generally found insufficient variation to meet this challenge. The observed heat tolerance of C. turcicum aligns well with the climate of the site of origin, characterized by an extreme temperature range. Note that the evidence for heat tolerance in $C$. turcicum is particularly compelling because the temperature data indicates that all species were subject to the same high reproductive phase temperature range, meaning that there were no heat escape opportunities. Nor is it likely that C. turcicum was more tolerant than the remaining wild species because of faster pod set, given that it's seed size is larger than both $C$. pinnatifidum and C. judaicum. Vegetative frost and reproductive chilling tolerance are also sorely lacking in domestic chickpea (Berger et al., 2012). Given, the cold nature of the of C. turcicum collection site, it is possible that this species may also harbor useful cold tolerance.

Bruchid resistance is also rare in domestic chickpea. Although more than 3,000 chickpea accessions were evaluated for resistance to $C$. chinensis at the International Center for Agricultural Research in the Dry Areas (ICARDA), no resistance was found in kabuli types. However, while some resistant desi chickpea with thick, rough or tuberculate seed coats have been identified (Reed et al., 1987), wild species such as C. echinospermum were found to be "immune" or free from damage (Eker et al., 2018). Annual Cicer species have already been screened for resistance to seed bruchid prior to the present study, and all accessions of C. echinospermum (100\%), some accessions of C. bijugum (42.9\%), C. judaicum (12.8\%), and C. reticulatum (5\%) were outlined to be free from the insect damage (Singh et al., 1998).

\section{CONCLUSION}

The following conclusions can be drawn from the present study:

- C. turcicum is a new, morphologically and genotypically distinct annual Cicer species which appears to be rare and found in different, climatically extreme environments than its Cicer relatives.

- ITS sequencing places it within the secondary genepool of domestic chickpea; this needs to be confirmed by crossing studies.

- Preliminary evaluation shows C. turcicum to harbor heat tolerance and bruchid resistance, but needs to be confirmed with wider evaluation. 
The above list suggests that C. turcicum will be useful for chickpea improvement if the species can be successfully crossed with the cultigen, but that it also represents an interesting opportunity for domestication and trait discovery studies if that is not the case. Regardless, C. turcicum is rare, and needs better understanding/protection. We suggest further survey and collection focusing on Elazig province in SE Anatolia, and registration in a "Critically Endangered (CR)" IUCN threat category.

\section{DATA AVAILABILITY STATEMENT}

The original contributions presented in the study are publicly available. This data can be found here: Sequences were submitted to GenBank with the accession numbers of AB198910.1.

\section{AUTHOR CONTRIBUTIONS}

CT, JB, and RSG designed the studies. JB, BA, and AK found the new species. CT and RSG described the new species. DS and HS performed the molecular study. TE and HS conducted heat tolerance and bruchid studies. CT, JB, RSG, and EW wrote and

\section{REFERENCES}

Abbo, S., Berger, J., and Turner, N. C. (2003). Evolution of cultivated chickpea: four bottlenecks limit diversity and constrain adaptation. Funct. Plant Biol. 30, 1081-1087. doi: 10.1071/FP03084

Abbo, S., Mesghenna, Y. T., and Van Oss, H. (2011). Interspecific hybridization in wild Cicer sp. Plant Breed. 130, 150-155. doi: 10.1111/j.1439-0523.2010.01838.x

Adak, A., Sari, D., Sari, H., and Toker, C. (2017). Gene effects of Cicer reticulatum on qualitative and quantitative traits in the cultivated chickpea. Plant Breed. 136, 939-947. doi: 10.1111/pbr.12547

Afonso-Grunz, F., Molina, C., Hoffmeier, K., Rycak, L., Kudapa, H., Varshney, R. K., et al. (2014). Genome-based analysis of the transcriptome from mature chickpea root nodules. Front. plant Sci. 5:325. doi: 10.3389/fpls.2014.00325

Ahmad, F. (1999). Random amplified polymorphic DNA (RAPD) analysis reveals genetic relationships among the annual Cicer species. Theor. Appl. Genet. 98, 657-663.

Ahmad, F., Slinkard, A. E., and Scoles, G. J. (1988). Investigations into the barriers to interspecific hybridization between Cicer arietinum L. and eight other annual Cicer spp. Plant Breed. 100, 193-198.

Ahmad, P., Abdel Latef, A. A., Hashem, A., Abd Allah, E. F., Gucel, S., and Tran, L. S. P. (2016). Nitric oxide mitigates salt stress by regulating levels of osmolytes and antioxidant enzymes in chickpea. Front. Plant Sci. 7:347. doi: 10.3389/fpls. 2016.00347

Alefeld, F. (1859). Ueber die vicieen. Oesterr. Bot. Z. 9, 352-366.

Badami, P. S., Mallikarjuna, N., and Moss, J. P. (1997). Interspecific hybridization between Cicer arietinum and C. pinnatifidum. Plant Breed. 116, 393-395. doi: 10.1111/j.1439-0523.1997.tb01019.x

Basu, P. S., Ali, M., and Chaturvedi, S. K. (2009). "Terminal heat stress adversely affects chickpea productivity in Northern India-strategies to improve thermotolerance in the crop under climate change," in W3 Workshop Proceedings: Impact of Climate Change on Agriculture, (New Delhi: International Society for Photogrammetry and Remote Sensing), 189-193.

Berger, J., Abbo, S., and Turner, N. C. (2003). Ecogeography of annual wild Cicer species: the poor state of the world collection. Crop Sci. 43, 1076-1090. doi: $10.2135 /$ cropsci2003.1076

Berger, J., Kahraman, A., Toker, C., Aydin, B., Aydogan, A., Bukun, B., et al. (2018). "New opportunities for chickpea improvement by the exploitation of wild revised the manuscript. All authors contributed to the article and approved the submitted version.

\section{FUNDING}

CT participated in collection mission with the project (113O216) financially support by TUBITAK. The collecting mission was jointly supported by a grant from the Australian Grain Research Development Corporation GRDC CSP00185 to JB, a cooperative agreement from the United States Agency for International Development under the Feed the Future Program AID-OAAA-14-00008 to D. R. Cook and Co-PIs EW and AK, and by a grant from the US National Science Foundation Plant Genome Program under Award IOS-1339346 to D. R. Cook, and coPI EW.

\section{ACKNOWLEDGMENTS}

We are thankful to the funding councils that supported this work, and to the reviewers for their thoughtful input on earlier versions of this manuscript.

Cicer," in Proceedings of the 7th International Food Legumes Research Conference (IFLRC) (Marrakesh, Morocco), 59.

Berger, J., Pushpavalli, R., Ludwig, C., Parsons, S., Basdemir, F., and Whisson, K. (2020). Wild and domestic differences in plant development and responses to water deficit in Cicer. Front. Plant Sci. 11:607819. doi: 10.3389/fgene.2020. 607819

Berger, J. D., Kumar, S., Nayyar, H., Street, K. A., Sandhu, J. S., Henzell, J. M., et al. (2012). Temperature-stratified screening of chickpea (Cicer arietinum L.) genetic resource collections reveals very limited reproductive chilling tolerance compared to its annual wild relatives. Field Crop. Res. 126, 119-129. doi: 10. 1016/j.fcr.2011.09.020

Berger, J. D., Shrestha, D., and Ludwig, C. (2017). Reproductive strategies in Mediterranean legumes: trade-offs between phenology, seed size and vigor within and between wild and domesticated Lupinus species collected along aridity gradients. Front. Plant Sci. 8:548. doi: 10.3389/fpls.2017.00548

Canci, H., and Toker, C. (2009a). Evaluation of annual wild Cicer species for drought and heat resistance under field conditions. Genet. Resour. Crop Evol. 56:1. doi: 10.1007/s10722-008-9335-9

Canci, H., and Toker, C. (2009b). Evaluation of yield criteria for drought and heat resistance in chickpea (Cicer arietinum L.). Agron. Crop Sci. 195, 47-54. doi: 10.1111/j.1439-037X.2008.00345.X

Ceylan, F. O., Sari, H., Sari, D., Adak, A., Erler, F., and Toker, C. (2019). Revealing of resistant sources in Cicer species to chickpea leaf miner, Liriomyza Cicerina (Rondani). Phytoparasitica 46, 635-643. doi: 10.1007/s12600-018-0699-x

Clarke, H. J., Wilson, J. G., Kuo, I., Lülsdorf, M. M., Mallikarjuna, N., Kuo, J., et al. (2006). Embryo rescue and plant regeneration in vitro of selfed chickpea (Cicer arietinum L.) and its wild annual relatives. Plant Cell Tissue Organ Cult. 85, 197-204. doi: 10.1007/s11240-005-9071-1

Contandriopoulos, J., Pamukçuoğlu, A., and Quézel, P. (1972). A propos de Cicer vivaces du pourtour. Mediterranéen Oriental. Biol. Gallo Hellen. 4, 3-18.

Czrepanov, S. K. (1981). Plantae Vasculares URSS. Leningrad: Nauka Press, 230.

Davis, P. H. (1970). “Cicer L," in Flora of Turkey and the Eastern Aegean Islands, ed. P. H. Davis (Edinburgh: Edinburgh University Press), 267-274.

Deokar, A. A., and Tar'an, B. (2016). Genome-wide analysis of the aquaporin gene family in chickpea (Cicer arietinum L.). Front. Plant Sci. 7:1802. doi: 10.3389/ fpls.2016.01802 
Devasirvatham, V., Gaur, P. M., Raju, T. N., Trethowan, R. M., and Tan, D. K. Y. (2015). Field response of chickpea (Cicer arietinum L.) to high temperature. Field Crops Res. 172, 59-71. doi: 10.1016/j.fcr.2014.11.017

Donmez, A. A. (2011). Cicer uludereensis Dönmez: a new species of Cicer (Chickpea) (Fabaceae) from around the Fertile Crescent, SE Turkey. Turk. J. Bot. 35, 71-76. doi: 10.3906/bot-1001-283

Doyle, J. J., and Doyle, J. L. (1990). Isolation of plant DNA from fresh tissue. Focus $12,39-40$.

Dwivedi, S., Goldman, I., and Ortiz, R. (2019). Pursuing the potential of heirloom cultivars to improve adaptation, nutritional, and culinary features of food crops. Agron 9:441. doi: 10.3390/agronomy9080441

Eker, T., Erler, F., Adak, A., Imrek, B., Guven, H., Tosun, H. S., et al. (2018). Screening of chickpea accessions for resistance against the pulse beetle, Callosobruchus chinensis L. (Coleoptera: Bruchidae). J. Stored Prod. Res. 76, 51-57. doi: 10.1016/j.jspr.2017.12.007

Erler, F., Ceylan, F., Erdemir, T., Toker, C., and Liu, T. X. (2009). Preliminary results on evaluation of chickpea, Cicer arietinum, genotypes for resistance to the pulse beetle, Callosobruchus maculatus. J. Insect Sci. 9, 1-7. doi: 10.1673/031.009.5801

Esen, A., Sari, H., Erler, F., Adak, A., Sari, D., Eker, T., et al. (2019). Screening and selection of accessions in the genus Pisum L. for resistance to pulse beetle (Callosobruchus chinensis L.). Euphytica 215:82. doi: 10.1007/s10681-019-23954

FAOSTAT (2020). Available online at: http://www.fao.org/faostat/ (accessed 15th December, 2020).

Farooq, M., Nadeem, F., Gogoi, N., Ullah, A., Alghamdi, S. S., Nayyar, H., et al. (2017). Heat stress in grain legumes during reproductive and grain-filling phases. Crop Pasture Sci. 68, 985-1005. doi: 10.1071/CP17012

Foyer, C., Lam, H. M., Nguyen, H., Siddique, K. H. M., Varshney, R. K., Colmer, T. D., et al. (2016). Neglecting legumes has compromised human health and sustainable food production. Nat. Plants 2:16112. doi: 10.1038/nplants.2016. 112

Guner, A., Aslan, S., Ekim, T., Vural, M., and Babac, M. T. (2012). Turkey List of Vascular Plants, Flora Series (1). Istanbul: Nezahat Gokyigit Botanik Bahcesi ve Flora Arastirmalari Yayini.

Hall, T. A. (1999). BioEdit: a user-friendly biological sequence alignment editor and analysis program for Windows 95/98/NT. Nucl. Acids. Symp. Ser. 41, 95-98.

Hatfield, J. L., and Prueger, J. H. (2015). “Challenge for future agriculture," in Crop Wild Relatives and Climate Change, eds R. Redden, S. S. Yadav, N. Maxted, M. E. Dulloo, L. Guarino, and P. Smith (Hoboken NJ: Wiley), 24-43.

Hijmans, R. J., Cameron, S. E., Parra, J. L., Jones, P. G., and Jarvis, A. (2005). Very high resolution interpolated climate surfaces for global land areas. Int. J. Climatol. 25, 1965-1978.

IPCC (2007). “The fourth assessment report of the IPCC," in Climate Change 2007Impacts, Adaptation and Vulnerability, eds M. Parry, O. Canziani, J. Palutikof, P. van der Linden, and C. Hanson (Cambridge: Cambridge University Press).

IUCN (2014). The IUCN Red List of Threatened Species. Version 2020-3. Available online at: https://www.iucnredlist.org. (accessed December 18, 2020)

Javadi, F., and Yamaguchi, H. (2004). Interspecific relationships of the genus Cicer L. (Fabaceae) based on trnT-F sequences. Theor. Appl. Genet. 109, 317-322. doi: 10.1007/s00122-004-1622-z

Jimenez-Lopez, J. C., Singh, K. B., Clemente, A., Nelson, M. N., Ochatt, S., and Smith, P. (2020). Legumes for global food security. Front. Plant Sci. 11:926.

Jukanti, A. K., Gaur, P. M., Gowda, C. L. L., and Chibbar, R. N. (2012). Nutritional quality and health benefits of chickpea (Cicer arietinum L.): a review. Br. J. Nutr. 108(Suppl. 1), S11-S26. doi: 10.1017/S0007114512000797

Kahraman, A., Pandey, A., Khan, M. K., Lindsay, D., Moenga, S., Vance, L., et al. (2017). Distinct Subgroups of Cicer echinospermum are associated with hybrid sterility and breakdown in interspecific crosses with cultivated chickpea. Crop Sci. 57, 3101-3111. doi: 10.2135/cropsci2017.06.0335

Khattak, S. U., Jan, K. Y., Hussain, N., and Khalil, K. (1995). Resistance of chickpea cultivars to pulse beetle, Callosobruchus maculatus. Sci. Khyber 8, 1-8.

Kivrak, K. G., Eker, T., Sari, H., Sari, D., Akan, K., Aydinoglu, B., et al. (2020). Integration of extra-large-seeded and double-podded traits in chickpea (Cicer arietinum L.). Agronomy 10:901. doi: 10.3390/agronomy10060901

Koseoglu, K., Adak, A., Sari, D., Sari, H., Ceylan, F. O., and Toker, C. (2017). Transgressive segregations for yield criteria in reciprocal interspecific crosses between Cicer arietinum L. and C. reticulatum Ladiz. Euphytica 213:116. doi: 10.1007/s10681-017-1903-7
Krishnamurthy, L., Gaur, P. M., Basu, P. S., Chaturvedi, S. K., Tripathi, S., Vadez, V., et al. (2011). Large genetic variation for heat tolerance in the reference collection of chickpea (Cicer arietinum L.) germplasm. Plant Genet. Resour. 9, 59-69. doi: 10.1017/S1479262110000407

Kumar, S., Stecher, G., Li, M., Knyaz, C., and Tamura, K. (2018). MEGA X: molecular evolutionary genetics analysis across computing platforms. Mol. Biol. Evol. 35, 1547-1549. doi: 10.1093/molbev/msy096

Kupicha, F. K. (1977). The delimitation of the tribe Vicieae (Leguminosae) and relationships of Cicer L. Bot. J. Linn. Soc. 74, 131-162. doi: 10.1111/j.1095-8339. 1977.tb01172.x

Ladizinsky, G. (1975). The origin of chickpea as indicated by seed protein electrophoresis. Israel J. Bot. 24, 183-189.

Ladizinsky, G., and Adler, A. (1976a). Genetic relationships among the annual species of Cicer L. Theor. Appl. Genet. 48, 197-203. doi: 10.1007/BF00527371

Ladizinsky, G., and Adler, A. (1976b). The origin of chickpea Cicer arietinum L. Euphytica 25, 211-217. doi: 10.1007/BF00041547

Mallikarjuna, N., Coyne, C., Cho, S., Rynearson, S., Rajesh, P. N., Jadhav, D. R., et al. (2011). "Cicer," in Wild Crop Relatives: Genomic and Breeding Resources, ed. C. Kole (Berlin: Springer), 63-82. doi: 10.1007/978-3-642-14387-8_4

Marques, E., Krieg, C. P., Dacosta, E., Bueno, E., Sessa, E., Penmetsa, R. V., et al. (2020a). The impact of domestication on above-and below-ground trait responses to nitrogen fertilization in wild and cultivated genotypes of chickpea (Cicer sp.). Front. Genet. 11:1506. doi: 10.3389/fgene.2020.57 6338

Marques, E., Kur, A., Bueno, E., and von Wettberg, E. (2020b). Defining and improving the "Rotational" and "Intercropping Value" of a crop using a plantsoil feedbacks approach. Crop Sci. 60, 2195-2203. doi: 10.1002/csc2.20200

McCarthy, C. (1996-1998). Chroma s vs. 1.45 (32 bit). Queensland: School of Health Science, Griffith University. Available online at: http://technelysium.com.au. /chromas.html (accessed August 2020).

New, M., Lister, D., Hulme, M., and Makin, I. (2002). A high-resolution data set of surface climate over global land areas. Clim. Res. 21, 1-25. doi: 10.3354/ cr021001

Newman, T. E., Jacques, S., Grime, C., Kamphuis, F. L., Lee, R. C., Berger, J., et al. (2020). Identification of novel sources of resistance to ascochyta blight in a collection of wild Cicer accessions. Phytopathology 111, 369-379. doi: 10.1094/ PHYTO-04-20-0137-R

Nozzolillo, C. (1985). Seedling morphology and anatomy of eight Cicer L. species and their taxonomic value. Canad. J. Bot. 63, 1-6.

Ozturk, M. (2011). Revision of the genus Cicer L. in Turkey via morphological, palynological, cytotaxonomical, molecular phylogenetic methods, and analyses of seed protein and element contents. Ph.D. thesis, The Graduate School of Natural and applied Science of Selcuk University, Konya.

Ozturk, M., Duran, A., and Hakki, E. E. (2011). Cicer floribundum var. amanicola Fabaceae, a new variety from south Anatolia, Turkey. Biyolojik Çeşitlilik Koruma 4, 44-51.

Ozturk, M., Duran, A., and Hakki, E. E. (2013). Cladistic and phylogenetic analyses of the genus Cicer in Turkey. Plant Syst. Evol. 299, 1955-1966. doi: 10.1007/ s00606-013-0850-6

Pang, J., Turner, N. C., Khan, T., Du, Y. L., Xiong, J. L., Colmer, T. D., et al. (2017). Response of chickpea (Cicer arietinum L.) to terminal drought: leaf stomatal conductance, pod abscisic acid concentration, and seed set. J. Exp. Bot. 68, 1973-1985. doi: 10.1093/jxb/erw153

Paul, P. J., Samineni, S., Sajja, S. B., Rathore, A., Das, R. R., Chaturvedi, S. K., et al. (2018). Capturing genetic variability and selection of traits for heat tolerance in a chickpea recombinant inbred line (RIL) population under field conditions. Euphytica 214:27. doi: 10.1007/s10681-018-2112-8

Penmetsa, R. V., Carrasquilla-Garcia, N., Bergmann, E. M., Vance, L., Castro, B., Kassa, M. T., et al. (2016). Multiple post-domestication origins of kabuli chickpea through allelic variation in a diversification-associated transcription factor. New Phytol. 211, 1440-1451. doi: 10.1111/nph.14010

Pokorny, L., Riina, R., Mairal, M., Meseguer, A. S., Culshaw, V., Cendoya, J., et al. (2015). Living on the edge: timing of Rand Flora disjunctions congruent with ongoing aridification in Africa. Front. Genet. 6:154. doi: 10.3389/fgene.2015. 00154

Pradhan, S., Bandhiwal, N., Shah, N., Kant, C., Gaur, R., and Bhatia, S. (2014). Global transcriptome analysis of developing chickpea (Cicer arietinum L.) seeds. Front. Plant Sci. 5:698. doi: 10.3389/fpls.2014.00698 
Rassulova, M. R., and Sharipova, B. A. (1992). New species of the genus Cicer from Tajikistan. Izv. Akad. Nauk Tadziksk SSR 1, 51-52.

Reed, W., Cardona, C., Sithanantham, S., and Lateef, S. S. (1987). "Chickpea insect pest and their control," in The Chickpea, eds M. C. Saxena and K. B. Singh (Wallingford: CABI Publishing), 283-318. doi: 10.1007/978-1-46149572-7

Reen, R. A., Mumford, M. H., and Thompson, J. P. (2019). Novel sources of resistance to root-lesion nematode (Pratylenchus thornei) in a new collection of wild Cicer species (C. reticulatum and C. echinospermum) to improve resistance in cultivated chickpea (C. arietinum). Phytopathology 109, 1270-1279. doi: 10. 1094/PHYTO-02-19-0047-R

Robertson, L. D., Singh, K. B., and Ocampo, B. (1995). A Catalog of Annual Cicer Species. Aleppo: ICARDA, 171.

Roorkiwal, M., Nayak, S. N., Thudi, M., Upadhyaya, H. D., Brunel, D., Mournet, P., et al. (2014). Allele diversity for abiotic stress responsive candidate genes in chickpea reference set using gene based SNP markers. Front. Plant Sci. 5:248. doi: $10.3389 /$ fpls.2014.00248

Sab, S., Lokesha, R., and Mannur, D. M. (2020). Genome-wide SNP discovery and mapping QTLs for seed iron and zinc concentrations in chickpea (Cicer arietinum L.). Front. Nutr. 7:559120. doi: 10.3389/fnut.2020.55 9120

Santos-Guerra, A., and Lewis, G. P. (1986). A new species of Cicer (LeguminosaePapilionoideae) from the Canary Islands. Kew Bull. 41, 459-462. doi: 10.2307/ 4102961

Schaefer, H., Hechenleitner, P., Santos-Guerra, A., Menezes de Sequeira, M., Pennington, R. T., and Kenicer, G. (2012). Systematics, biogeography, and character evolution of the legume tribe Fabeae with special focus on the middleAtlantic island lineages. BMC Evol. Biol. 12:250. doi: 10.1186/1471-2148-1225

Singh, K. B., Malhotra, R. S., and Saxena, M. C. (1995). Additional sources of tolerance to cold in cultivated and wild Cicer species. Crop Sci. 35, 1491-1497. doi: 10.2135/cropsci1995.0011183X003500050037x

Singh, K. B., Malhotra, R. S., and Saxena, M. C. (1992). Registration of ILC 8262, a cold-tolerant germplasm line of chickpea. Crop Sci. 32, 558.

Singh, K. B., Ocampo, B., and Robertson, L. D. (1998). Diversity for abiotic and biotic stress resistance in the wild annual Cicer species. Genet. Resour. Crop Evol. 45, 9-17. doi: 10.1023/A:1008620002136

Smykal, P., Coyne, C. J., Ambrose, M. J., Maxted, N., Schaefer, H., Blair, M. W., et al. (2015). Legume crops phylogeny and genetic diversity for science and breeding. CRC Crit. Rev. Plant Sci. 34, 43-104. doi: 10.1080/07352689.2014.897904

Smýkal, P., Trněný, O., Brus, J., Hanáček, P., Rathore, A., Roma, R. D., et al. (2018). Genetic structure of wild pea (Pisum sativum subsp. elatius) populations in the northern part of the Fertile Crescent reflects moderate cross-pollination and strong effect of geographic but not environmental distance. PLoS One 13:e0194056. doi: 10.1371/journal.pone.0194056

Talip, M., Adak, A., Kahraman, A., Berger, J., Sari, D., Sari, H., et al. (2018). Agro-morphological traits of Cicer reticulatum Ladizinsky in comparison to C. echinospermum PH Davis in terms of potential to improve cultivated chickpea (C. arietinum L.). Genet. Resour. Crop Evol. 65, 951-962. doi: 10.1007/ s10722-017-0587-0

Tekin, M., Sari, D., Catal, M., Ikten, C., Smykal, P., Penmetsa, R. V., et al. (2018). Eco-geographic distribution of Cicer isauricum PH Davis and threats to the species. Genet. Resour. Crop Evol. 65, 67-77. doi: 10.1007/s10722-017-0509-1
Toker, C. (2005). Preliminary screening and selection for cold tolerance in annual wild Cicer species. Genet. Resour. Crop Evol. 52, 1-5. doi: 10.1007/s10722-0051743-5

Toker, C., Berger, J., Kahraman, A., Aydogan, A., Can, C., Bukun, B., et al. (2014). Cicer reticulatum Ladizinsky, progenitor of the cultivated chickpea (C. arietinum L.). Legume Perspect. 5, 26-27.

TSMS (2020). Available online at: https://www.mgm.gov.tr/eng/forecast-cities. aspx?m=ELAZIG (accessed Dec 20, 2020).

Ture, C., and Bocuk, H. (2010). Distribution patterns of threatened endemic plants in Turkey: a quantitative approach for conservation. J. Nat. Conserv. 18, 296-303. doi: 10.1016/j.jnc.2010.01.002

Upadhyaya, H. D., Bajaj, D., Narnoliya, L., Das, S., Kumar, V., Gowda, C. L. L., et al. (2016). Genome-wide scans for delineation of candidate genes regulating seed-protein content in chickpea. Front. Plant Sci. 7:302. doi: 10.3389/fpls.2016. 00302

Upadhyaya, H. D., Dwivedi, S. L., Ambrose, M., Ellis, N., Berger, J., Smykal, P., et al. (2011). Legume genetic resources: management, diversity assessment, and utilization in crop improvement. Euphytica 180, 27-47. doi: 10.1007/s10681011-0449-3

van der Maesen, L. J. G. (1984). "Taxonomy, distribution and evolution of the chickpea and its wild relatives," in Genetic Resources and Their Exploitation Chickpeas, Faba beans and Lentils, eds J. R. Witcombe and W. Erskine (Dordrecht: Springer), 95-104. doi: 10.1007/978-94-009-6131-9_9

van der Maesen, L. J. G. (1987). "Origin, history and taxonomy of the chickpea," in The Chickpea, eds M. C. Saxena and K. B. Singh (Wallingford: CABI publishing), 11-34.

van der Maesen, L. J. G., Maxted, N., Javadi, F., Coles, S., and Davies, A. M. (2007). "Taxonomy of Cicer revisited," in Chickpea Breeding and Management, eds S. S. Yadav, R. Redden, W. Chen, and B. Sharma (Wallingford: CABI publishing), $14-46$.

van der Maesen, L. J. G. (1972). Cicer L., A monograph of the Genus with Special Reference to the Chickpea (Cicer arietinum L.), its ecology and Cultivation, Vol. 72. Wageningen: Mededelingen. Landbouwhoogeschool, 9-136.

von Wettberg, E. J., Chang, P. L., Basdemir, F., Carrasquila-Garcia, N., Korbu, L. B., Moenga, S. M., et al. (2018). Ecology and genomics of an important crop wild relative as a prelude to agricultural innovation. Nat. Commun. 9, 1-13. doi: 10.1038/s41467-018-02867-z

White, T. J., Bruns, T., Lee, S., and Taylor, J. (1990). "Amplification and direct sequencing of fungal ribosomal RNA genes for phylogenetics," in PCR protocols: A guide to Methods and Applications, eds M. Innis, D. Gelfand, J. Sninsky, and T. White (San Diego, CA: Academic Press), 315-322.

Conflict of Interest: The authors declare that the research was conducted in the absence of any commercial or financial relationships that could be construed as a potential conflict of interest.

Copyright ( 2021 Toker, Berger, Eker, Sari, Sari, Gokturk, Kahraman, Aydin and von Wettberg. This is an open-access article distributed under the terms of the Creative Commons Attribution License (CC BY). The use, distribution or reproduction in other forums is permitted, provided the original author(s) and the copyright owner(s) are credited and that the original publication in this journal is cited, in accordance with accepted academic practice. No use, distribution or reproduction is permitted which does not comply with these terms. 